\title{
Priests, Conflicts and Property Rights: the Impacts on Tenancy and Land Use in Brazil
}

\author{
${ }^{1}$ Ostrom Workshop, Indiana University, Bloomington, IN; Natural Bureau of Economic Research, USA, E-mail: \\ ljalston@indiana.edu \\ ${ }^{2}$ Department of Economics, University of Brasília, Brasilia, Brazil
}

\begin{abstract}
:
Compared to the rest of the world, farmers in Brazil rely relatively little on tenant contracts. In agriculture, career mobility is associated with moving up the agricultural ladder from working for wages to renting to owning (Alston, L.J., and J.P. Ferrie. 2005. "Time on the Ladder: Career Mobility in Agriculture," 1890-1938 The Journal of Economic History 65(04): 1058-1081. Cambridge University Press). Alone, this fact may not present a puzzle, but coupled with the large number of landless peasants and large amounts of unused land, the question is, Why don't landowners with unused or underutilized land negotiate land rental contracts with the landless.? In Brazil, this avenue for advancement has been hurt by a reluctance of owners to rent in areas experiencing land conflict. The lack of rentals is an important issue because Brazil is geographically a large country, roughly the size of the continental United States and has an expanding agricultural frontier, some of which is cutting into the Amazon. If the lack of land rentals is pervasive across Brazil and also signals inefficiency in production, the total magnitude is likely to be large when summed across the country.
\end{abstract}

Keywords: tenancy, brazil

DOI: 10.1515/me-2018-0003

\section{Introduction}

Compared to the rest of the world, farmers in Brazil rely relatively little on tenant contracts. ${ }^{1}$ In agriculture, career mobility is associated with moving up the agricultural ladder from working for wages to renting to owning (Alston and Ferrie 2005). Alone, this fact may not present a puzzle, but coupled with the large number of landless peasants and large amounts of unused land, the question is, Why don't landowners with unused or underutilized land negotiate land rental contracts with the landless? ${ }^{2}$ In Brazil, this avenue for advancement has been hurt by a reluctance of owners to rent in areas experiencing land conflict. The lack of rentals is an important issue because Brazil is geographically a large country, roughly the size of the continental United States and has an expanding agricultural frontier, some of which is cutting into the Amazon. If the lack of land rentals is pervasive across Brazil and also signals inefficiency in production, the total magnitude is likely to be large when summed across the country. Some scholars have attributed the lack of rentals to a fear by landlords that renters will become de facto owners because of existing legislation making it extremely costly to evict tenants, if they are in default with their rental payments Buainain et al. (2008), Conning and Robinson (2007), De Janvry, Macours, and Sadoulet (2002), De Janvry and Sadoulet (1989), Deininger and Chamorro (2004), and De Janvry, Macours, and Sadoulet (2002). A similar fear of rentals may arise from land reform projects De Janvry, Macours, and Sadoulet (2002); Rezende (2006). For example, in Brazil, land should be put to productive use or it may be subject to compensated expropriation Alston, Libecap, and Mueller (1999a). Renting land could be deemed unproductive use by land reform agencies and as a result, owners would be fearful of renting Brandão, Bastos Filho, and Brandão (2001), Buainain et al. (2008), and Deininger and Chamorro (2004); Jaramillo (2001); World Bank (1994: 199-200). An additional explanation for the lack of rentals rests on the labor and capital intensity of different crops. Some land may not be worth the opportunity cost of capital, and the return to applying labor via a rental contract may be close to zero. As such landowners may opt to leave land vacant as a potential store of value or in some cases collateral for credit to be used elsewhere. Alternatively, if farmers are fearful that land may be invaded and expropriated if left idle, they might opt to rent to demonstrate use and possession, particularly if the landlord has reason to trust the renter. To the extent that land conflict and land reform policies affect land rentals and encourage expansion of the agricultural frontier into the Amazon, deforestation will result. By estimating the impact of land conflict on land rentals and land use we can better judge the deficiencies in current land reform policies and this can be a guide for better policies in the future. 
Better land reform policies can be trebly important: (1) lives can be saved and poor people's lot improved if tenancy is a step on the agricultural ladder; (2) land reform policies can improve the productivity of agriculture in Brazil; and (3) land reform policies can slow the rate of deforestation in the Amazon, which holds the largest stock of tropical forests in the world.

We test for the impact of land conflict on land rentals use by using municipio (county) level data from the Brazilian censuses along with data on land conflicts from the Pastoral Land Commission (CPT). The key empirical challenge in the estimation of this impact arises because land rentals and conflicts are likely jointly determined, as the existence of tenancy may induce higher levels of conflicts. We address this issue by using data on the number of priests in the municipio in order to instrument for conflict. Catholic priests played a key role in organizing social movements, such as the Landless Peasant Movement (MST), which would go on to be a major vector of social unrest and violence. We use priest data from 1966 to estimate conflicts in the 1985-1996 period. This conflict data is used, in turn, to estimate agricultural contract choice in 1996. This timing is central to our empirical strategy because the priest data is prior to great lurch to the left of the Catholic Church in the 1970s, when it started focusing more directly on agrarian issues. In order to address the concern that the distribution of priests might not be exogenous to the choice of contracts, as the Church might have placed more priests where there were more rental contracts in 1966, in Section 3.4 we regress the number of priests in 1985 against the number of priests in 1966 plus a series of controls, including the area in fixed-rental contracts, the area in sharecropping and the area occupied by squatters in 1970. The number of priests in 1985 is predicted only by the number of priests in 1966 and distance from the state capital. Importantly, past contract choices are not found to influence the future allocation of priests. This suggests that the distribution of priests during the period when the Church was intensely involved in agrarian issues (1970-1985) was not much different from that in the preceding, more conservative, phase of the Church in Brazil. Given this highly inertial nature of priest allocation over time, their distribution in 1966 can thus be taken as supplying exogenous variation to the incidence of the treatment - conflict - for the purpose of explaining contract choice 30 years later.

In the next section, we present a literature review and our conceptual framework. Section 3 describes the data and our empirical strategy. The estimations of the first and second stages are in Section $4 \mathrm{v}$, together with discussion of the results and considerations about robustness. Section 5 concludes.

\section{Theoretical hypotheses about tenancy}

\subsection{Literature review}

The theoretical literature on tenancy is voluminous. We assume that the standard explanations for the efficiency of sharecropping and tenancy - share and fixed rent - are now public knowledge. By standard explanations, we mean risk and transaction costs. ${ }^{3}$ In short, depending on the endowments of landlords and workers, as well as their preferences towards risk, there exist conditions such that the optimal operator status can be either owner-operator (with only household or with hired wage workers); sharecropper; share tenant; or fixed-rent tenant. ${ }^{4}$

In the United States in the nineteenth and early twentieth centuries, there was a life cycle to contract choice, which agricultural economists referred to as the agricultural ladder. The 'ladder' referred to the movement with age from the statuses of wage worker to tenant to owner Alston and Ferrie (2005); Alston and Kauffman (1997) and (Alston and Kauffman 1998). Climbing the rungs on the ladder meant acquiring human and physical capital as well as improving socioeconomic status. Most transaction cost explanations for contract choice rest on the costs of information, negotiation, supervision and enforcement. The plethora of explanations based on transaction costs (or market failures) arose because many economists initially took to heart the Marshallian inefficiency argument and then had difficulty explaining why various forms of tenancy and sharecropping have been so ubiquitous over time and space (Marshall 1890). Now, economists are turning the issue on its head: why are there some regions of the world that rely too little on tenancy and sharecropping, given the existence of transaction costs? Consistent figures are difficult to find, but both North America and Europe stand out in the high percentage of land and farm establishments rented. For example, de Janvry, Macours and Sadoulet (2002; pp. 24-25) present data showing that farmers in the United States leased $45 \%$ of agricultural land in 1988, and in Europe the figures for 1995 range from a low of $12 \%$ for Ireland to above $60 \%$ for Belgium, France and Germany. The figure for the United States in 2007 was 38.5\% (US Department of Agriculture 2007, Vol. 1, Table 58). Figure 1 shows the evolution of tenancy in Brazil from 1920 to 1995. The total number of farm establishments that were rented fell by nearly half from 1970 (20\%) to 1995 (11\%), while the corresponding area fell from a high of $10 \%$ in 1940 to a low of $2.5 \%$ in 1995. 


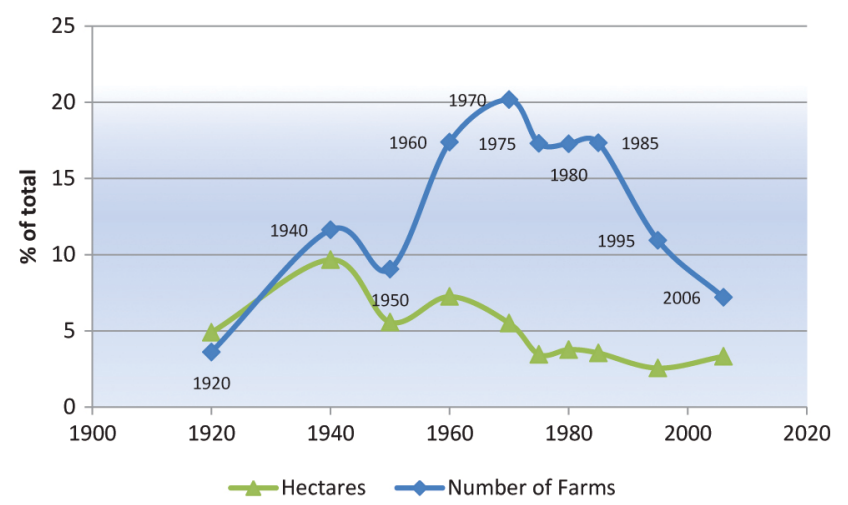

Figure 1: Evolution of tenancy over time in Brazil (Source: IBGE (2007). Data for 2006 from the 2006 Agricultural Census and may not be perfectly comparable).

Recent explanations for the lack of rentals in developing countries rest on the insecurity of property rights. Insecure property rights may reduce the prevalence of rentals because of difficulties in conflict resolution. If it is difficult to evict tenants who do not meet the rental terms, landlords may respond by using wage labor or by only renting to those they trust such as relatives and friends. ${ }^{5}$ In some countries, tenants receive the right to purchase the land that they rent and thus, not surprisingly, landlords may be reluctant to rent. ${ }^{6}$ Some governments prohibit land rentals on land redistributed through land reform projects, either de facto (because there are frequently delays in assigning formal titles) or de jure (because of a fear of absentee beneficiaries). ${ }^{7}$

De Janvry and Sadoulet (1989) examine the impact of land reform in Latin America by integrating the choice of agricultural organization with the political economy of reform to analyze what they call 'the lost game of Latin American land reform.' The equilibrium they see prevailing in most of Latin America is one where the threat of reform in the 1960s induced large- and medium-sized farms to modernize and increase their productivity so as to preempt any form of expropriation, which in turn increased their economic and political power, thus hindering any future attempts at reform even though reform could potentially lead to large net social gains. Their approach is a good description of the history of tenancy in Brazil where legislation put into place in the early 1960s was explicitly hostile to tenancy and sharecropping, inducing landowners to expel masses of tenants from their lands in the following decades.

Besley et al. (2011) and Conning and Robinson (2007) analyze the impact of property rights on tenancy in India through models and empirical tests that are closely related to the objective of this article. In both cases, insecurity of property rights arises from reforms pushed by the government to protect tenants and/or landless peasants. These reforms make renting out less attractive to landowners, thus leading to less use of tenancy contracts. Conning and Robinson (2007) link a model of contract choice to a political economy model of potential property rights reform. In the contract choice model, the key feature is the existence of an essential non-traded factor (skill) that is required for production in addition to land and labor. Because this factor cannot be traded, the efficient organization of agriculture requires farm sizes that are proportional to the distribution of this factor, with land being leased from those who do not have enough of the essential factor to those with an excess relative to their own holding of land. This second-best situation will hold if property rights are secure. But if landowners have reasons to fear that future events might bring a change in the security of property rights, such as a land-to-the-tiller reform, then the agents might optimally choose to forgo the potential gains of entering into tenancy contracts so as to avoid the losses that will be borne if the threat does materialize. The approach includes two factors increasing the transaction costs of renting land: a non-traded factor and insecure property rights, with both reform and the extent of tenancy being endogenously determined. The most important testable hypothesis that emerges from the model is that anything that increases the threat to property rights will lower the incidence of land rentals. We test this hypothesis with county-level data for Brazil in Section 4.

Besley et al. (2011) utilize a natural experiment to test the impact of insecure property rights. Besley et al. take advantage of a reorganization of state boundaries in India in 1956 that left districts with very similar social and economic characteristics but subject to different types of tenancy and land reforms. Their model focuses on the reaction of landowners to the constraints and uncertainty that arise from different land reforms. They find that reform led to a reduction in tenancy as many landlords opted to sell their land. This resulted in a reduction of land inequality as land was transferred to poorer individuals, including many previous tenants. This redistribution did not benefit all social groups, however, for members of the middle castes were more likely to have the means to purchase land than the lower castes, who were typically laborers or sharecroppers rather than tenants. The reforms thus led to an increase in landlessness among the lower castes. The decrease in sharecropping was accompanied by an increase in the agricultural wage as landlords who no longer relied on tenants or sharecroppers increased their demand for workers, but this was not sufficient to compensate the welfare loss of the poorer sub-group. 


\subsection{Conceptual framework}

In this subsection, we describe the mechanisms through which property rights affect the decision of landowners and peasants to enter into tenancy contracts. We focus on a landowner's decision of contract choice, that is, who will use the land. Because our data for Brazil is at the municipio (county) level, it is important to understand a mechanism operating at the municipio level. In any given municipio there are $N$ landowners, each with different personal characteristics (e. g., wealth, age, education, experience and acquaintances), and different land characteristics (e. g., location, fertility, access, topography, water and type of title). Because of these varied characteristics, there are different dispositions by each landowner to rent out all or some of their land. The landowner makes his decision by comparing the expected net present value of holding the land under tenancy, $\Pi^{T}$, versus the net present value of the best alternative use, $\Pi^{A}$, which could be using the land herself, leaving the land idle, or selling it. ${ }^{8}$ When $\Pi^{T}>\Pi^{A}$ the landowner would opt to rent the land and when $\Pi^{T}<\Pi^{A}$ the best alternative use would be chosen, with the landowner indifferent in the case of equal expected net present values.

In any given municipio, there is a distribution of landowners according to the difference between the NPVs from using the land under tenancy compared to the next best alternative use. This distribution ranges from landowners on the left for whom tenancy is less attractive than the alternative use, to those on the right for whom the expected returns from renting the land are higher than the expected returns from using or selling the land. There is therefore a cutoff point in the distribution where $\Pi^{T}=\Pi^{A}$. Given the historical lack of tenancy in Brazil and Latin America, one would expect much of the mass of the distribution in these countries to be to the left of the cutoff.

The issue that we analyze in this article is: what happens to the distribution of landowners if property rights in the municipio become less secure? That is, what is the impact of weaker property rights on the extent of tenancy in a given municipio? For those landowners in either of the tails of the distribution, small changes in property rights security will not impact their decisions. Tenancy is either very attractive or excessively risky (unprofitable) for them, and their decision would not be affected. But for those closer to the cutoff point, the change in property rights security might lead to a different decision. In which direction does the deterioration of property rights move the distribution? The answer to this question depends on what happens to both $\Pi^{T}$ and $\Pi^{A}$. Because both of these net present values will likely fall when property rights become less secure, the direction and magnitude of the shift of the distribution relative to the cutoff point depend on the change in landowners' expectations of profits in response to the change in property rights. If the security of property rights reduces the expected NPV from tenancy more than it does the expected NPV from the best alternative use, then the distribution moves to the left and the extent of tenancy in the municipio decreases. If $\Pi^{A}$ decreases more than $\Pi^{T}$, then the distribution moves to the right and tenancy becomes more prevalent.

What are the channels through which a decrease in the security of property rights affects $\Pi^{T}$ and $\Pi^{A}$ ? There can be both direct and indirect effects. The direct effect on tenancy is the case when the landowner perceives a greater risk of having her land invaded or expropriated if she rents it out. This would be the case of a landto-the-tiller type of land reform (see Conning and Robinson, 2007) or as explicitly stated in the 1964 Brazilian Land Statute (Article 20): "The expropriations by the Public Power will be directed towards: ... V - areas that present high incidence of renters, sharecroppers or squatters." The direct effect on the alternative use would be to force the landowner to make the land more productive than optimal (which might be to leave it idle) so as to preempt an invasion. This is the reaction found by several studies on property rights, such as Besley (1995), Carter and Olinto (2003), Place and Otsuka (2002), among others.

But even when the landowner does not perceive a very high probability of having her land directly impacted, there can be important indirect effects from weaker property rights that reduce her expected return from the land. In the case of tenancy, the landowner might perceive an increased risk that the person to whom she rents will not abide by the contract, for example, by not paying the rent in full, in a timely manner or defaulting completely. In addition, a landowner may worry that the tenant does not care for the land by making the needed investments. According to Almeida (2002), who interviewed a sample of landowners who were, or had been, engaged in renting out land in Brazil, these are major concerns when deciding whether to enter in tenancy contracts. Less secure property rights in a municipio alter the landowners' perception of the risk of having the contract violated by the rentee and affect the probability of redress through the courts or government. In Brazil, where the legislation, policy and public opinion clearly side with the weaker part in agrarian relations (Alston, Libecap, and Mueller 2010), the result of higher insecurity in the municipio would be to reduce the expected NPV of a tenancy contract. Finally, the indirect impact of more insecure property rights on a landowner who opts not to rent is to reduce the value of his land, which affects access to credit and opportunities to sell the land.

The question is whether the direct and indirect impacts of property rights insecurity will be larger on $\Pi^{T}$ or on $\Pi^{A}$ (or will have no effect on either). This is essentially an empirical issue, though our prior from the qualitative accounts is that the decrease in Brazil in the property rights of landowners will reduce ten- 
ancy. There is evidence in both directions in the literature for several different countries around the world (see Besley 1995; Besley et al. 2011; Binswanger, Deininger, and Feder 1995; Carter and Olinto 2003; Conning and Robinson 2007; Deininger and Ali 2008; Ghatak and Roy 2007; Pande and Udry 2006; Place and Otsuka 2002; among others). There is also evidence that each of these channels is at play in shaping the incentives of Brazilian landowners (see Alston, and Ferrie 1999; Alston, Libecap, Mueller 2000; Hidalgo et al. 2010; 2009; 2006; 2006). Insecure property rights make landowners reluctant to rent out the land, but if they are unwilling to use their land, which was often the case in Brazil in the period we studied, renting out may offer protection against invasion and expropriation. The empirical test in this article determines whether renting increases or decreases in the face of greater insecurity of property rights in Brazil. If we find that municipios that experienced more conflicts, our measure of property rights insecurity, have a greater extent of tenancy, then the net effect of conflicts will have been to move the distribution to the right, and we can conclude that tenancy is less sensitive to weaker property rights than use of the land by the landowner. Alternatively, if we find (and expect) that conflicts reduce tenancy, we can conclude that the negative effect of weak property rights on tenancy outweighs its positive incentives for landowners to put idle land to use through renting or selling.

\section{Data and empirical strategies}

\subsection{Introduction}

We utilize data that includes all municipios (counties) in Brazil and contains variables that measure both the agro-climatic/geographic determinants of contract choice, as well as the political economy determinants. We estimate a system where the dependent variable of each equation is the percent of total farm area that is held under each of the four categories included in the Brazilian Agricultural Census: fixed rent, sharecropper, owner and squatted/occupant (no formal title). ${ }^{9}$ In order to measure the extent to which contract choice is determined by the natural and physical endowment of each county, we use as independent variables the percent of total farmland that is placed under cotton, rice, coffee, cane, beans, manioc, corn and soybeans. Each crop has its own physical attributes and agro-climatic requirements that determine where they can be grown and the best farm size, given relative prices. At the same time, each crop's attributes, along with attributes of the landowner, imply that a given type of contract would be best for dealing with the problems inherent in its production. Coffee, for example, is a perennial crop, by nature labor-intensive, has few economies of scale and consequently tends to be produced more productively by smaller owner-run farms than by fixed-rent contracts. ${ }^{10}$ Other variables that control for the impact of endowments, capturing elements of geography, transport costs and climate, are the distance to state capital, transport costs to São Paulo, existence of train stations, latitude and longitude. ${ }^{11}$

The major objective of the empirical test is to ascertain whether the choice of agricultural organization in terms of contract choice is essentially determined by endowments, that is, agro-climatic and geographic factors, or whether political economy factors also have an effect, distorting the choice of contract in terms of efficiency, given the crop mix in the county. To this end, we use data collected by the Pastoral Land Commission (CPT) of the Catholic Church to measure the extent of land-related violence in each county from 1985 to 1995 . In those places that experienced violence and conflict, land owners and claimants expect a greater probability of intervention from the government, generally in the form of expropriation and redistribution of land to landless peasants through the creation of settlement projects (Alston, Libecap, and Mueller 1999a, 1999b; Alston, Libecap, Mueller 2000; 2010). The struggle for land in Brazil since the mid-1980s has essentially revolved around the strategy by organized groups of landless peasants, such as the MST, of selectively invading properties that are legally vulnerable to expropriation (regions with high tenancy, low productivity, weak title and/or large holdings) so as to attract the government and force it to expropriate in their favor. The impact of conflicts affects not only the decision of whether to plant or not, but also whether to engage in tenancy contracts. One of the main reasons for this is the Land Statute of 1964, which still underpins all of the land-related legislation. The Land Statute of 1964 imposes very rigid limits for tenancy contracts and explicitly states that farms in rental arrangements may be preferable candidates for redistribution. ${ }^{12}$ The origins of this bias in the legislation may be a reaction to the historically very unequal distribution of wealth and power in the Brazilian countryside. Nevertheless, as noted in Bank (1994: 199):

the perverse effect is to reduce access to exactly those people the regulations were designed to protect. In addition, the Land Statute contains other provisions that relate the incidence of renting and sharecropping to the possibility of expropriation of farms, that is, the law provides that "expropriation ... will be applied to: ... areas with high incidence of renters, sharecroppers and squatters." The threat of expropriation may have been much more effective in constraining the rental market and sharecropping 
arrangements than the provisions that regulate such arrangements. This seemed to be particularly true when claims for land reform were increasing.

Another strong legal impediment to tenancy in Brazil is the 1963 Rural Worker Statute, which extended the set of legal labor benefits already held by urban workers to those in agriculture (Rezende and Kreter 2007; The Economist 2011: 43). ${ }^{13}$ The statute set regional minimum wages, established the 13th salary, holidays, payment for overtime, 48-hour workweek and limited the employers' acceptable justifications for firing. It is argued by several authors that even though this regulation was not well enforced, it was far from innocuous, and the imposition of these encumbrances led landowners to dispense hordes of rural workers, both tenants and wage workers, and to switch towards using temporary workers (Carvalho 1991; IPARDES; Nichols 1971; Ribeiro and Stolf 1975; Saint 1980).

Given this nature of land and labor policy in Brazil and in accordance with our conceptual framework, the expectation is that the variable that measures conflict will be negatively related to both the percentage of area in fixed rent and sharecropping and positively related to the area in owner-farmed properties, even after controlling for endowments. Although labor legislation and those parts of the land legislation that directly refer to tenancy impose impediments to this type of contracting, land reform legislation may provide incentives in the other direction. As noted above, land reform today in Brazil starts with invasion of unproductive properties by organized landless peasant groups with the government providing land reactively. In this scenario, it may make sense for a landowner who wants to hold land but not yet put it to use, to lease the land as a means to make it productive and thus immune to expropriation. ${ }^{14}$ Our results will allow us to test which effect of conflicts dominates in Brazil, or if they cancel each other out. If we find a positive and statistically significant impact of land conflict on fixed rent and sharecropping, then we can conclude that land reform provides incentives for landowners to enter into more rental arrangements than they would in the absence of conflicts, and the low levels of tenancy in Brazil would be even lower without conflicts. This result would be in line with that found in Ghana by Besley (1995), in Uganda by Place and Otsuka (2002), in Paraguay by Carter and Olinto (2003), in Africa by Pinckney and Kimuyu (1994) and for Brazil by Vertova (2006). If, however, we find the coefficient of conflicts in the fixed rent and sharecropping equations to be negative, this will be strong evidence of a perverse effect of land legislation on the choice of agricultural contract leading to inefficiencies of the type predicted in the models by Besley et al. (2011), Conning and Robinson (2007), and De Janvry and Sadoulet (1989). ${ }^{15}$

\subsection{Instruments for the first-stage estimation of conflict}

Our major objective is to determine the relative impacts of conflicts and endowments on contract choice and land use. However, there is a potential endogeneity of conflicts that would render OLS estimates inconsistent, given that land invasions and other forms of violence may be more probable in areas where there is a greater incidence of tenancy arrangements and farms without formal title. Similarly, certain types of land uses, such as forests or unused land, are characterized as unproductive and may attract invasion and expropriation. We confirm this endogeneity using a Hausman-Wu test, which we present in the results section (Table 4). Therefore, we need an appropriate instrument for conflict in order to estimate a first-stage equation that will allow us to control for the potential simultaneity. The instrument must be correlated with conflicts, but should have no direct link to contract choice or land use. The dependent variable of the second-stage regressions is contract choice and land use in 1996. Because we want to determine the impact of conflict on contract choice and land use, the conflict data aggregates all land-related conflicts in each county from 1985 to $1995 .{ }^{16}$

An appropriate instrument should be a variable that has a strong relationship with rural conflicts. A natural place to look is at groups and organizations that helped landless peasants to organize and fight for their rights. There has long been a struggle for land in Brazil leading to violence and conflicts. But, with the exception of a few isolated historical cases, it was only in the early 1980s that there came about a systematic increase in the number of organized groups of landless peasants throughout the entire country. As is often the case with grassroots movements, the widespread emergence of organized landless peasants groups in the 1980s in Brazil was not a spontaneous phenomenon, but rather the result of other social groups that sought to catalyze social change by organizing and prompting peasants into action. The main motivation for these groups was the extremely poor living conditions and high levels of exploitation of the rural poor in Brazil, which are essential features of the country's historical legacy. A measure of the presence of such catalyzing groups across municipios would thus be a strong candidate for an instrumental variable for conflicts, though we would still have to certify that this was in no way affected by the existence of tenancy arrangements or specific of land uses.

Three potential catalyzing groups are rural unions, opposition political parties and the Catholic Church. Due to lack of data on rural unions and probable violation of the exclusion restriction for opposition parties, we focus on the Church. During the 1970s, the Catholic Church in Brazil was undergoing a process of change in its political stance, and its relation to the military regime and ruling elites. In this period, it became the "most 
progressive Church in Latin America" (Bruneau 1985: 271) and explicitly announced a 'preferential option for the poor'. By the early 1980s, the Church was explicitly engaged in organizing groups of landless peasants throughout the country to demand their rights (Mainwaring and Wilde 1989). As noted by Houtzager (2001):

The church was an ideal institutional host. It is a transnational institution with firm roots in rural communities. It is able, on the one hand, to garner critical resources, information, and political support from national and international sources and, on the other, it is a local actor represented by the Bishop, the parish priest and local pastoral agents. Progressive clergy and lay activists in Brazil were able to mobilize rural social groups (primarily small farmer and peasant groups) and local resources through the church's impressive associational web, its own elaborate organizational structure, and a popular religious identity. The church's myriad pastoral programs, the CPT and other church entities, linked community leaders and activists to each other and to the national movements of the left emerging in the transition. ... Religion conferred a degree of legitimacy and provided protection from repression by local elite groups and the national state. This depth of the church's involvement in organizing rural social groups and its direct, self-conscious, sponsorship of these groups' involvement in a national movement, distinguishes the church as institutional host from the church as a simple ally. Houtzager (2001): 23-24

This key role of the Church in organizing rural communities is highlighted by one of the founders of the MST, João Pedro Stédile in Menezes Neto (2007):

The CPT (Pastoral Land Commission) was the practical application of the Theology of Liberation, which was an important contribution to the landless peasants' struggle from the ideological point of view. The priests, pastoral agents and pastors discussed with the peasants the need for them to organize themselves. The Church stopped doing messianic work and saying to the peasant: 'Wait and you will go to heaven.' Now they started saying 'You have to get organized and fight to solve your problems here on earth'.

Adriance (Adriance 1991, 1994; 1995), Hewitt (1990), Krischke (1991), Mainwaring (1986), and Maybury-Lewis (1994) recognize the critical role of the Catholic Church in enabling the rural organizations that changed the nature of the struggle for land in the 1980s. Therefore, a variable that measures the strength of the church's presence in a given municipio during this period should correlate with the existence of conflicts over land. We do have data on the number of priests per municipio for several years starting in 1966, so this variable may be used as an instrument for conflict if it also passes the exclusion restriction (investigated below).

In order for priests to be appropriate instruments for conflict in our contract choice regressions, it is necessary that priests are distributed across municipios in a manner unrelated to land contracts and land use. It may seem natural that if the Church cared about landlessness they would tend to focus their presence in those areas where there was a greater incidence of landownership concentration, sharecropping, inequality and other potentially explosive agrarian issues. In order to investigate the determinants of the location of priests, we analyzed the historical timing of the Catholic Church's involvement in agrarian issues in order to pick a period before it had expressed concerns or taken actions to systematically assist the landless and rural poor. Fortunately, there is a distinctly recognizable and well-documented trajectory of the Church's ideological and practical shifts over the past decades that we can exploit to assure that our measure of priest allocation is not linked to the way land was being used. During the 1970s in most of Latin America, and most prominently in Brazil, the Catholic Church gradually abandoned its traditional position as an ally of the prevailing regimes and ruling elites to take an explicit stand in favor of the poor and dispossessed. The first manifestation of this change was the meeting of the Latin American episcopate in Medellin, Columbia, in 1968. The meeting produced a document, which instead of being based on religious dogma and doctrine was inspired by Dependency Theory and Liberation Theology, with clear anti-capitalist rhetoric professing the need for the Church to play a central role in combating poverty and inequality (Brito 2010). During the 1970s, this point of view sparked much controversy and disagreement within the Church as conservative forces resisted these new ideas. The culminating point of this power struggle was in a subsequent meeting of the Latin American episcopate in Puebla, Mexico, in 1979 after which the episcopate issued a new document. Even though the conservative forces counted with the presence of the newly elected Pope John Paul II, who attended the meeting, the outcome was a clearly progressive document in which the Church officially established the famous 'preferential option for the poor.'

In Brazil, the Church had supported the military coup of 1964, but as the regime became increasingly repressive, it shifted to a clearly opposing position by the mid-1970s (Skidmore 2003: 247). In 1975, the Brazilian Catholic Church created the CPT, demonstrating a growing concern for agrarian issues, though at that point it focused only on Amazonian states. But most importantly, in 1980, a General Assembly of the Brazilian Bishops released an official document called "The Church and Problems of the Land," in which it emphatically affirmed its intention to play a direct role in improving the lot of the rural population. After a long diagnosis 
directly blaming the capitalist system for the exploitation of rural workers and landless peasants, the document proposes to take the following (among other) lines of action as guiding principles of its pastoral commitments:

2nd - We commit to denounce openly inequitable and violent situations that are committed in our dioceses and parishes and to combat the causes of those injustices and violence

3rd - We reaffirm our support for the initiative of workers' organizations placing our power and means at the disposal of their cause ... Our pastoral action, careful not to substitute the initiatives of the people, will stimulate the conscious and critical participation of workers in unions, associations, commissions and other forms of cooperation, so that they can be truly autonomous and free, defending their interests and coordinating the demands of their members and of their entire class. (CNBB - Confederação Nacional dos Bispos Brasilieros: paragraphs 97 and 98. Our emphasis in bold.)

This document in 1980 can be interpreted as marking the point at which the Church in Brazil started to actively and directly engage with agrarian issues. There may have been individual and isolated instances in the 1960s and increasingly in the 1970s where priests and other lay church members got involved in such issues. But this document marks the turning point where this involvement became an explicit policy of the Church as a whole. It is noteworthy that the bishops' document was approved by an overwhelming majority of 174 votes against 4 (Martins 1980: 39). The following years, from 1980 to 1985, would be the heyday of the Church's involvement in land-related issues. It is during this period that the MST was incubated, having been officially founded in 1984. Our conflict data begins in 1985 partly because it was at this point that land invasions started to become a sufficiently widespread and systematic phenomenon to merit record keeping.

Yet, after the first half of the 1980s, the Church's direct association with land-related issues started to wane. In part, this happened as a result of their own success in jumpstarting grassroots organizations such as the MST, unions and cooperatives that eventually became autonomous and self-organized. Also, with re-democratization in 1985, several other mediating groups that had been suppressed during the military period (re)emerged and actively competed with the Church for the role as the main institutional link for the new peasant groups, foremost among these political parties, NGOs and unions. Other determinants of the decline of the Church's direct involvement in agrarian issues include the direct pressure from the Vatican under Pope John Paul II (who was strongly anti-Marxist) and staunch competition from evangelical movements (Adriance 1992; Serbin 2000). Hewitt (1990) noted that:

In more recent years the Church has become increasingly confused with respect to support for societal transformation. Not only has the upper hierarchy become more fractious, a tendency toward conservatism has also become apparent. The Church as an institution has returned to previous modes of political influence and appears to be abandoning its support for grassroots movements in favor of direct pressure on political policy makers. (pg. 148)

From the description above, one can visualize a graph of the evolution of the Church's direct involvement in agrarian issues over time that starts at low levels in the 1960s, gradually increases until the mid-1970s when it bends upward, spiking in the early 1980s, only to drift back down systematically to moderately low levels by the 1990s. This timing is central for our identification strategy. The dependent variables in our analysis (land contracts and land use) are from 1996. The key explanatory variable (conflicts as a proxy for property rights) is from the period of 1985-1996. By using priest data from 1966 as an instrument for conflicts, that is, before the Church demonstrated the inclination and propensity to get directly involved in land-related issues, this variable can be viewed as randomized for the purpose of estimating conflicts. The allocation of priests in the early 1980s may have been affected by the Church's decision to directly interfere with rural issues at that time. But the allocation of priests in 1966 was not contaminated by this change that would only take place some 15 years later. Menezes (2009: 1) notes that those isolated cases prior to the early 1960s where religion took part in the struggle against rural strife "took place out of institutionalized churches, especially the Catholic Church." For our purposes, the allocation of priests by 1966 can thus be assumed to have been determined by a series of historical and tradition-related factors with roots prior to that time, with agrarian issues not featured prominently among them. This 'randomized' allocation persisted until the early 1980 s due to institutional inertia, that is, the Church simply did not change its distribution of priests significantly over time. ${ }^{17}$ The correlation of the number of priests per 1,000 rural population in 1966 and 1985 is a high 0.81 . This suggests that even when the Church did make the decision to get directly involved in land-related issues, it probably did so not so much by changing the number of priests in different locations as by encouraging those priests who were already there to be more proactive on agrarian issues.

The withdrawal of the Church from direct hands-on support for peasant movements by the mid-1990s is also important for our identification strategy. If landholders in 1996 had their decision to enter into tenancy arrangements affected by the greater or lesser presence of priests in the region, our identification strategy could 
be compromised. However, as we have argued, by that time the Church no longer played a direct part in the struggle for land. Instead, other groups representing landless peasants, most notably the MST, replaced the previous role of the Catholic Church. Thus, the marker that landowners would use to gauge the risk involved in entering into tenancy contracts or in planting different crops, would not be how many priests there are in the region but rather the presence of mobilized groups of landless peasants with their characteristic red flags flying and waiting for the right moment to launch another invasion.

In order to better capture the catalyzing effect of priests over rural organization, we interact the priest variable with another variable that measures the 'frontierness' of the municipio. The idea is that frontier areas are more contentious, with less well-defined property rights than areas that are already well established (GarciaJimeno and Robinson 2009). Similarly, in these areas, the priests suffer less monitoring from hierarchical superiors that tend to be less progressive and thus have greater liberty to pursue more radical interventions. This strategy allows us to identify how the effect of priests on conflicts varies with the socio-political nature of the county in question.

In order to measure the 'frontierness' of a given county, we take advantage of the fact that over time, the number of municipios in Brazil has greatly increased through the subdivision of counties into two or more autonomous entities. This movement has led to an increase from 643 municipios in 1872 to 5,507 in 2000. The evolution of the number of municipios suggests that the creation of new municipios accompanies the expansion of the economic, demographic and agricultural frontiers (Reis, Pimentel, and Alvarenga 2009). As the frontier expands, there is a natural tendency for political-administrative decentralization by creating new counties out of localities within the original municipio. Our index of 'frontierness' uses this correlation to create a measure of the municipios that have undergone a greater process of frontier expansion. The subdivisions that take place over time have made comparisons of county-level data over time very difficult. Fortunately, the Census has recently created minimum comparable areas (MCA) that aggregate the data in such a way that makes comparison possible (IBGE 1984; Reis, Pimentel, and Alvarenga 2009). In our empirical tests, we use the MCAs for 1970-2000, which aggregate the 5,507 counties in year 2000 into 3,659 comparable areas. We create our index of 'frontierness' by counting the number of municipios in 2000 that are in each of these MCAs. The great majority of MCAs $(2,894$ out of 3,659) did not undergo any modification from 1970 to 2000, indicating a consolidated frontier process. The remaining 765 MACs underwent varying numbers of subdivisions, with the distribution varying from $482 \mathrm{MCAs}$ that subdivided twice, to one that subdivided 52 times. We use our 'frontier' variable in the conflict equation both to access its own impact on conflict as well as interact it with our data on priests. An alternative to try to capture the same effect is the distance from the state capital, which we also use; however, the frontier index is superior, as the furthest places are not always where the frontier has expanded the most.

\subsection{Data}

Our estimation procedure involves a first-stage regression to obtain the predicted level of conflicts per hectare in each county, and then a second stage where contract choice or land use is the dependent variable. This involves four general groups of variables that we describe briefly here, leaving the details to Appendix A. Our observations are at the level of minimum comparable areas for the period 1970-2000, which comprises a total of 3,659 observations. Some of the variables were available for downloading from IPEADATA (www.ipeadata.gov.br) in the MCA format, but other variables, such as the conflict and priest data, and even some of the agricultural census variables, had to be aggregated to fit the MCA format. ${ }^{18}$

The first group of variables is from the Agricultural Census (IBGE). This includes the contract choice variables ( $\%$ of total farmland), crop mix (\% of total farmland), land use variables (e.g., natural forest, planted forest, permanent crops, temporary crops, and pasture, all in \% of total farm land), average size of farms (hectares), and tractors per hectare. We use agricultural data for both 1995 and 1985, sometimes to calculate growth rates.

We use conflict data from the CPT of the Catholic Church. The CPT released data on conflicts in yearly reports since 1985. The data cover threats, murders, murder attempts and land invasions (occupations), by $m u-$ nicipio. We used this data to create a simple additive index. In this index, we gave a weight of 10 to occupations because these are central to land conflicts and involve large numbers of people. A non-weighted index yielded essentially the same results. ${ }^{19}$ In creating the index, the total number of violence-related incidents is divided by the number of farms in the muncipio.

Our third set of variables measures the presence of the Catholic Church in each county. We use data from Catholic Hierarchy (http://www.catholic-hierarchy.org/), which provides not only the number of Catholics and of priests per diocese but even the names of all the bishops. In order to make the diocese-level data compatible with the county and MCA data, we used the Catholic Census of Brazil compiled by CERIS CERIS Centro de Estudos Religiosos e Investigações Sociais (). The data on priests is available for several different years starting in the early twentieth century. We chose to use data for 1966 because this is prior to the Church's active engagement with landless peasants, and it is also the earliest year for which the data cover all municipios 
given our use of minimum comparison areas. We divide the number of priests by rural population to account for the different diocese sizes.

Our final group of variables captures assorted effects. There are variables that control for geographic and climatic variations, such as distance of the county to the state capital, transportation cost to São Paulo, number of train stations and latitude and longitude coordinates. Other variables control for economic and political effects, such as county GDP. We present descriptive statistics in Table 1.

Table 1: Descriptive statistics.

\begin{tabular}{|c|c|c|c|c|c|}
\hline Variable & $\mathbf{N}$ & Mean & $\begin{array}{l}\text { Stand. } \\
\text { Dev. }\end{array}$ & Min & $\operatorname{Max}$ \\
\hline Conflicts per 1000 farms & 3659 & 0.7877 & 5.918 & 0 & 283.582 \\
\hline Priests per rural population 1966 & 3647 & 15.670 & 66.913 & 0.052 & 3562.50 \\
\hline Priests per rural population 1985 & 3631 & 16.658 & 42.231 & 0.073 & 831.683 \\
\hline Frontier & 3659 & 1.505 & 2.262 & 1 & 53 \\
\hline Political opposition 1982 (\%seats - MDB) & 3659 & 0.340 & 0.243 & 0 & 1 \\
\hline Political opposition 1996 (\% seats - PT) & 3659 & 0.025 & 0.057 & 0 & 0.615 \\
\hline Population density 1995 & 3640 & 240.62 & $13,572.77$ & 0.0087 & $818,792.3$ \\
\hline GDP growth 1985-1995 (log) & 3643 & -0.165 & 0.677 & -4.806 & 4.062 \\
\hline Tractors per hectare1995 & 3640 & 0.004 & 0.007 & 0 & 0.130 \\
\hline Average size of farms (hec.) 1995 & 3640 & 93.720 & 174.619 & 0.104 & 4296.837 \\
\hline Cattle per hectare1995 & 3640 & 0.556 & 1.227 & 0 & 63.462 \\
\hline Latitude & 3659 & -16.491 & 7.644 & -33.519 & 3.843 \\
\hline Longitude & 3659 & 44.881 & 5.833 & 32.411 & 72.67 \\
\hline Rural/Urban Population (1995) & 3621 & 1.071 & 1.631 & 0.0004 & 63.661 \\
\hline Population growth 1985-1995 & 3659 & 0.121 & 0.666 & -0.960 & 38.349 \\
\hline Natural Forest (\% total farm area) 1995 & 3640 & 0.154 & 0.136 & 0 & 0.900 \\
\hline Planted Forest (\% total farm area) 1995 & 3640 & 0.022 & 0.054 & 0 & 0.799 \\
\hline Temporary crops (\% total farm area) 1995 & 3640 & 0.163 & 0.174 & 0 & 0.993 \\
\hline Planted pasture (\% total farm area) 1995 & 3640 & 0.231 & 0.217 & 0 & 0.901 \\
\hline Natural Pasture (\% total farm area) 1995 & 3640 & 0.250 & 0.184 & 0 & 0.911 \\
\hline Permanent crops (\% total farm area) 1995 & 3640 & 0.053 & 0.093 & 0 & 1 \\
\hline Usable but not used (\% total farm area) 1995 & 3640 & 0.048 & 0.069 & 0 & 0.601 \\
\hline Fallow area (\% total farm area) 1995 & 3640 & 0.031 & 0.039 & 0 & 0.313 \\
\hline$\%$ of land in Fixed Rent contracts, 1995 & 3640 & 0.049 & 0.073 & 0 & 0.781 \\
\hline \% of land in Sharecropping contracts, 1995 & 3640 & 0.021 & 0.041 & 0 & 0.714 \\
\hline$\%$ of land farmed by owner, 1995 & 3640 & 0.892 & 0.104 & 0 & 1.00 \\
\hline$\%$ of land squatted/occupied, 1995 & 3640 & 0.038 & 0.063 & 0 & 1.00 \\
\hline Cotton, \% 1995 & 3640 & 0.003 & 0.012 & 0 & 0.315 \\
\hline Rice, \% 1995 & 3640 & 0.008 & 0.026 & 0 & 0.709 \\
\hline Coffee, \% 1995 & 3640 & 0.012 & 0.038 & 0 & 0.429 \\
\hline Cane, \% 1995 & 3640 & 0.039 & 0.142 & 0 & 1.00 \\
\hline Beans, \% 1995 & 3640 & 0.024 & 0.047 & 0 & 0.715 \\
\hline Manioc, \% 1995 & 3640 & 0.009 & 0.027 & 0 & 0.580 \\
\hline Corn, \% 1995 & 3640 & 0.048 & 0.067 & 0 & 0.851 \\
\hline Soybeans, \% 1995 & 3640 & 0.021 & 0.136 & 0 & 0.901 \\
\hline Distance to state capital $(\mathrm{km})$ & 3659 & 240.467 & 158.039 & 0 & 1365.742 \\
\hline Transport cost to São Paulo (index) & 3658 & 1475.81 & 1114.83 & 0 & $10,511.92$ \\
\hline Train stations & 3659 & 0.485 & 1.696 & 0 & 63 \\
\hline
\end{tabular}

\subsection{A preliminary test of the instrument}

To determine if priests pass the exclusion restriction, we investigate whether the past incidence of tenancy affected the way the Church subsequently allocated priests. In Table 2, we investigate the determinants of the allocation of priests by regressing priests against five sets of variables: i) their own lagged values; ii) the incidence of tenancy (sharecropping and fixed rent) in the past; iii) economic and social variables (population growth, GDP growth, schooling and income); iv) geographic variables (distance to state capital, frontier index, latitude and longitude); and v) state dummies. The purpose is to see if the allocation of priests in 1985 (the height of the Church's involvement in agrarian issues) was affected by the existence of tenancy in the previous decade. If we find this link, then the instrument would not satisfy the exclusion restriction. 
Table 2: Determinants of priest allocation.

\begin{tabular}{|c|c|c|}
\hline $\begin{array}{l}\text { Dep. Variable: Priest } \\
\text { per } 1000 \text { rural pop in } 1985\end{array}$ & $\mathbf{I}$ & II \\
\hline Priest/1000 rural pop 1966 & $\begin{array}{l}1.09^{* * *} \\
(11.96)\end{array}$ & $\begin{array}{l}1.09^{* * *} \\
(11.48)\end{array}$ \\
\hline Fixed rent \% (1970) & & $\begin{array}{l}3.109 \\
(0.40)\end{array}$ \\
\hline Sharecrop \% (1970) & & $\begin{array}{l}-10.553 \\
(-1.15)\end{array}$ \\
\hline Squatted/Occupied \% (1970) & & $\begin{array}{l}-2.178 \\
(-0.78)\end{array}$ \\
\hline Population growth $1970-80$ & & $\begin{array}{l}-0.012 \\
(-0.01)\end{array}$ \\
\hline GDP growth $1970-80$ & & $\begin{array}{l}0.063 \\
(0.42)\end{array}$ \\
\hline Income (1970) & & $\begin{array}{l}-0.00001 \\
(-1.41)\end{array}$ \\
\hline Schooling (1970) & & $\begin{array}{l}1.453 \\
(1.53)\end{array}$ \\
\hline Distance to state capital & & $\begin{array}{l}-0.008^{* *} \\
(-2.41)\end{array}$ \\
\hline Frontier & & $\begin{array}{l}0.088 \\
(0.90)\end{array}$ \\
\hline Latitude & & $\begin{array}{l}0.009 \\
(0.03)\end{array}$ \\
\hline Longitude & & $\begin{array}{l}0.327 \\
(1.55)\end{array}$ \\
\hline Constant & $\begin{array}{l}0.805 \\
(0.75)\end{array}$ & $\begin{array}{l}-23.517^{*} \\
(-1.88)\end{array}$ \\
\hline Number of observations & Total: 3631 & Total: 3631 \\
\hline State dummies (27 states) & No & Yes \\
\hline $\mathrm{R}^{2}$ adjusted & 0.64 & 0.64 \\
\hline $\mathrm{F}(\mathrm{k}, \mathrm{n}-\mathrm{k})$ & 142.94 & 74.79 \\
\hline Prob $>F$ & 0.0000 & 0.0000 \\
\hline
\end{tabular}

OLS regression. t-stats in parentheses. Robust standard errors. Statistical significance $1 \%{ }^{* * *} .5 \%{ }^{* *}, 10 \%{ }^{*}$.

In Column I, we regressed the number of priests (per 1,000 rural population) in 1985 against the number of priests in 1966. The estimated coefficient is close to 1 and statistically significant at $1 \%$, which indicates a strong inertia in the distribution of priests. The value for the R-squared (0.64) shows that the past allocation in 1966 explains most of the variation of the distribution of priests in 1985, suggesting little change over time. In Column II, the tenancy, economic, social and geographic variables are added, as well as state dummies. The past value of the distribution of priests dominates all other variables with the same near-unitary coefficient of Column I, confirming the highly inertial character of the allocation of priests. Distance to the state capital is the only other variable that is significant, reflecting that there are fewer priests further from the central regions. Given that the adjusted R-squared is the same in both specifications indicates that for this period, looking solely at past allocations of priests is sufficient to understand current allocations with very little information being gained from other variables. The fact that the distribution of priests in 1985 was not affected by the existence of tenancy in the previous fifteen years suggests that the Church did not use a strategy of placing more priests where there were more tenants and squatters. The finding that the allocation of priests does not vary much over time suggests that the strategy in the late 1970s and early 1980s was to increase the level of effort of all priests towards agrarian issues, given their current allocation, that is, working through the intensive rather than the extensive margin. Furthermore, because we use priests in 1966 as an instrument, which is 30 years earlier than the contract choice and land use dependent variables in our main regressions, we have a strong case that the allocation of priests was randomized for the purpose of our main regressions determining contract choices and land use. The notion that the Church sought to target more priests where there was more tenancy and sharecropping is also undermined by the main result in the next section, which finds a negative relation between priests and these types of contracts, with the mechanism being through a positive impact of priests on conflicts. 


\section{Estimation and results}

\subsection{First stage: determinants of rural conflict}

In Table 3, we present the results of the first-stage regression where we estimate the determinants of rural conflict per 1,000 farms using priests as an instrument. We used a Tobit procedure because there are 2,974 observations censored at zero, that is, without any conflicts from 1985 to 1995 . Priests are interacted with the frontier index, so the estimated impact of priests on rural conflict has to be interpreted taking into account the coefficients of all three variables: priests, frontier and the interaction term. ${ }^{20}$ The interpretation is that for municipios where the frontier index equals 1 , that is, those that have been consolidated since 1970, the estimated coefficient for priests is negative but not significant. For municipios with a frontier index greater than or equal to 2, the impact of priests on conflict is positive, significant and growing as the index increases. An additional priest per 1,000 rural population in a county with a frontier index of 10 leads to 0.31 additional conflicts per 1,000 farms. At a frontier index of 20 , this value jumps to 0.71 conflicts. The results indicate that priests serve as catalysts for land-related conflict by organizing social movements. The interaction qualifies this perception by showing that it is stronger in areas that are currently undergoing a more intense frontier process. Besides these impacts through priests, the frontier index also has a positive and significant direct effect on conflicts, with a unit increase in the index leading to an additional 0.03 conflicts per 1,000 farms. A McDonald and Moffit (1980) decomposition of the marginal effects of the independent variables on the number of conflicts shows that $19 \%$ of these effects work through muncipios that already have conflicts (above the limit) and $81 \%$ through those that do not. Importantly for policy, this implies that policies that seek to reduce the determinants of rural conflicts should not focus exclusively in areas that have already experienced violence, as the potential for conflict is often latent even in areas that have been apparently peaceful in the past.

Table 3: Determinants of rural conflict - first-stage equation.

\begin{tabular}{|c|c|}
\hline Dep. Var.: Violence 1985-1996 & \\
\hline Priests per rural population & $\begin{array}{l}-0.629^{* * *} \\
(-10.47)\end{array}$ \\
\hline Frontier & $\begin{array}{l}0.233^{* * *} \\
(5.01)\end{array}$ \\
\hline Interaction: Priest $x$ Frontier & $\begin{array}{l}0.287^{* * *} \\
(8.21)\end{array}$ \\
\hline $\begin{array}{l}\text { Agricultural GDP growth 1985- } \\
1995 .\end{array}$ & $\begin{array}{l}2.683^{* * *} \\
(4.68)\end{array}$ \\
\hline Distance to state capital & $\begin{array}{l}0.004 \\
(1.39)\end{array}$ \\
\hline Transport cost to São Paulo & $\begin{array}{l}0.001 \\
(1.26)\end{array}$ \\
\hline Number of train stations & $\begin{array}{l}0.150 \\
(0.80)\end{array}$ \\
\hline Latitude & $\begin{array}{l}0.195 \\
(0.84)\end{array}$ \\
\hline Longitude & $\begin{array}{l}-0.359 \\
(-1.35)\end{array}$ \\
\hline Cattle per hectare1995 & $\begin{array}{l}-0.656 \\
(-0.67)\end{array}$ \\
\hline Tractors per hectare1995 & $\begin{array}{l}-1240.63^{* * *} \\
(-8.57)\end{array}$ \\
\hline Rural/Urban Population (1995) & $\begin{array}{l}-1.650^{* * *} \\
(-4.28)\end{array}$ \\
\hline Population growth 1985-1995 & $\begin{array}{l}1.236^{* * *} \\
(2.65)\end{array}$ \\
\hline Population density 1995 & $\begin{array}{l}0.010^{* * *} \\
(4.68)\end{array}$ \\
\hline Cotton, $\%$ of total farm area & $\begin{array}{l}-25.481 \\
(-0.62)\end{array}$ \\
\hline Rice, $\%$ of total farm area & $\begin{array}{l}-19.454 \\
(-0.95)\end{array}$ \\
\hline Coffee, $\%$ of total farm area & $\begin{array}{l}-46.258^{* * *} \\
(-2.65)\end{array}$ \\
\hline
\end{tabular}




\begin{tabular}{ll} 
Cane, \% of total farm area & $9.899^{* * *}$ \\
& $(3.71)$ \\
Beans, \% of total farm area & $-52.060^{* * *}$ \\
& $(-3.79)$ \\
Manioc, \% of total farm area & -24.394 \\
& $(-1.45)$ \\
Corn, \% of total farm area & 6.119 \\
& $(0.72)$ \\
Soy Beans, \% total farm area & $23.556^{* * *}$ \\
& $(4.08)$ \\
Constant & 19.994 \\
& $(1.10)$ \\
Number of observations & Total: 3616 \\
& Censored at $0: 2967$ \\
State Dummies (27 states) & Uncensored: 648 \\
Pseudo $\mathrm{R}^{2}$ & Yes \\
$\chi^{2}(55)$ & 0.14 \\
Prob $>\chi^{2}$ & 1131.91 \\
\hline
\end{tabular}

Tobit Estimation. t-stats in parentheses. Statistical significance: $1 \%{ }^{* * *} .5 \%{ }^{* *}, 10 \%{ }^{*}$. Weighted by the number of county subdivision from 1970 to 2000.

Table 4: Determinants of contract choice.

\begin{tabular}{|c|c|c|c|c|}
\hline & Fixed Rent (\%) & $\begin{array}{l}\text { Sharecropper } \\
(\%)\end{array}$ & Owner (\%) & $\begin{array}{l}\text { Squatted/Occupant } \\
(\%)\end{array}$ \\
\hline Conflict per 1000 farms & $\begin{array}{l}-0.008^{* * *} \\
(-3.60)\end{array}$ & $\begin{array}{l}-0.006^{* * *} \\
(-4.21)\end{array}$ & $\begin{array}{l}0.010^{* * *} \\
(3.39)\end{array}$ & $\begin{array}{l}0.004^{* *} \\
(2.50)\end{array}$ \\
\hline Cotton, $\%$ of total farm area & $\begin{array}{l}0.428^{* * *} \\
(4.21)\end{array}$ & $\begin{array}{l}0.181^{* * *} \\
(2.61)\end{array}$ & $\begin{array}{l}-0.689^{* * *} \\
(-4.99)\end{array}$ & $\begin{array}{l}0.080 \\
(1.05)\end{array}$ \\
\hline Rice, $\%$ of total farm area & $\begin{array}{l}0.275^{* * *} \\
(5.97)\end{array}$ & $\begin{array}{l}0.227^{* * *} \\
(7.19)\end{array}$ & $\begin{array}{l}-0.512^{* * *} \\
(-8.18)\end{array}$ & $\begin{array}{l}0.011 \\
(0.30)\end{array}$ \\
\hline Coffee, $\%$ of total farm area & $\begin{array}{l}-0.146^{* * *} \\
(-4.14)\end{array}$ & $\begin{array}{l}0.042^{*} \\
(1.73)\end{array}$ & $\begin{array}{l}0.124^{* * *} \\
(2.60)\end{array}$ & $\begin{array}{l}-0.021 \\
(-0.78)\end{array}$ \\
\hline Cane, $\%$ of total farm area & $\begin{array}{l}0.187^{* * *} \\
(17.77)\end{array}$ & $\begin{array}{l}0.068^{* * *} \\
(9.47)\end{array}$ & $\begin{array}{l}-0.225^{* * *} \\
(-15.73)\end{array}$ & $\begin{array}{l}-0.030^{* * *} \\
(-3.83)\end{array}$ \\
\hline Beans, $\%$ of total farm area & $\begin{array}{l}-0.050 \\
(-1.40)\end{array}$ & $\begin{array}{l}0.089^{* * *} \\
(3.61)\end{array}$ & $\begin{array}{l}-0.167^{* * *} \\
(-3.42)\end{array}$ & $\begin{array}{l}0.129^{* * *} \\
(4.76)\end{array}$ \\
\hline Manioc, $\%$ of total farm area & $\begin{array}{l}0.062 \\
(1.21)\end{array}$ & $\begin{array}{l}0.097^{* * *} \\
(2.78)\end{array}$ & $\begin{array}{l}-0.695^{* * *} \\
(-9.98)\end{array}$ & $\begin{array}{l}0.536^{* * *} \\
(13.94)\end{array}$ \\
\hline Corn, $\%$ of total farm area & $\begin{array}{l}-0.042^{*} \\
(-1.70)\end{array}$ & $\begin{array}{l}0.021 \\
(1.23)\end{array}$ & $\begin{array}{l}0.019 \\
(0.57)\end{array}$ & $\begin{array}{l}0.002 \\
(0.11)\end{array}$ \\
\hline Soy Beans, $\%$ total farm area & $\begin{array}{l}0.218^{* * *} \\
(13.21)\end{array}$ & $\begin{array}{l}0.032^{* * *} \\
(2.82)\end{array}$ & $\begin{array}{l}-0.219^{* * *} \\
(-9.73)\end{array}$ & $\begin{array}{l}-0.032^{* *} \\
(-2.55)\end{array}$ \\
\hline Frontier & $\begin{array}{l}-0.0004^{* *} \\
(-2.28)\end{array}$ & $\begin{array}{l}0.00003 \\
(0.21)\end{array}$ & $\begin{array}{l}0.0009^{* * *} \\
(4.05)\end{array}$ & $\begin{array}{l}-0.0005^{* * *} \\
(-4.05)\end{array}$ \\
\hline GDP growth 1985-1995 & $\begin{array}{l}0.006^{* *} \\
(2.47)\end{array}$ & $\begin{array}{l}0.004^{* *} \\
(2.40)\end{array}$ & $\begin{array}{l}-0.013^{* * *} \\
(-3.87)\end{array}$ & $\begin{array}{l}0.003^{* *} \\
(1.52)\end{array}$ \\
\hline Latitude & $\begin{array}{l}-0.004^{* * *} \\
(-4.60)\end{array}$ & $\begin{array}{l}-0.0001 \\
(-0.15)\end{array}$ & $\begin{array}{l}0.005^{* * *} \\
(4.64)\end{array}$ & $\begin{array}{l}-0.001^{* *} \\
(-2.15)\end{array}$ \\
\hline Longitude & $\begin{array}{l}-0.001 \\
(-0.93)\end{array}$ & $\begin{array}{l}-0.0007 \\
(-1.01)\end{array}$ & $\begin{array}{l}-0.003^{* *} \\
(-2.01)\end{array}$ & $\begin{array}{l}0.005^{* * *} \\
(5.79)\end{array}$ \\
\hline Distance to state capital & $\begin{array}{l}-0.000002 \\
(-0.19)\end{array}$ & $\begin{array}{l}0.00002^{* * *} \\
(2.66)\end{array}$ & $\begin{array}{l}0.00001 \\
(0.58)\end{array}$ & $\begin{array}{l}-0.00003^{* * *} \\
(3.23)\end{array}$ \\
\hline Transport cost to São Paulo & $\begin{array}{l}0.000003 \\
(0.73)\end{array}$ & $\begin{array}{l}-0.0000002 \\
(-0.10)\end{array}$ & $\begin{array}{l}-0.00001^{* *} \\
(-2.52)\end{array}$ & $\begin{array}{l}0.00001^{* * *} \\
(3.68)\end{array}$ \\
\hline Number of train stations & $\begin{array}{l}0.002^{* * *} \\
(3.57)\end{array}$ & $\begin{array}{l}-0.0001 \\
(-0.21)\end{array}$ & $\begin{array}{l}-0.003^{* * *} \\
(-2.85)\end{array}$ & $\begin{array}{l}0.0003 \\
(0.60)\end{array}$ \\
\hline Population density 1995 & $\begin{array}{l}0.00002^{* *} \\
(2.06)\end{array}$ & $\begin{array}{l}0.000001 \\
(1.47)\end{array}$ & $\begin{array}{l}-0.00002^{* *} \\
(-1.96)\end{array}$ & $\begin{array}{l}-0.000003 \\
(-0.52)\end{array}$ \\
\hline Rural/Urban Population 1995 & $\begin{array}{l}-0.002^{* *} \\
(-2.32)\end{array}$ & $\begin{array}{l}-0.0008 \\
(-1.56)\end{array}$ & $\begin{array}{l}-0.00005 \\
(-0.05)\end{array}$ & $\begin{array}{l}0.003^{* * *} \\
(4.59)\end{array}$ \\
\hline Population growth 1985-1996 & 0.003 & 0.002 & -0.002 & -0.003 \\
\hline
\end{tabular}




\begin{tabular}{lllll} 
& $(1.12)$ & $(1.36)$ & $(-0.62)$ & $(-1.61)$ \\
Tractor per hectare growth 1985- & -0.243 & $0.512^{* * *}$ & $-0.775^{* *}$ & $0.507^{* * *}$ \\
1995 & $(-1.06)$ & $(3.26)$ & $(-2.48)$ & $(2.94)$ \\
Cattle per hectare1995 & -0.002 & 0.0002 & $0.007^{* *}$ & $-0.005^{* * *}$ \\
& $(-0.65)$ & $(0.11)$ & $(2.06)$ & $(-2.96)$ \\
Constant & 0.077 & 0.075 & $1.100^{* * *}$ & $-0.248^{* * *}$ \\
& $(1.09)$ & $(1.54)$ & $(11.42)$ & $(-4.68)$ \\
Number of observations & Total: 3616 & Total: 3616 & Total: 3616 & Total: 3616 \\
State dummies (27 states) & Yes & Yes & Yes & Yes \\
Pseudo R & 0.17 & 0.05 & 0.18 & 0.22 \\
$\chi^{2}(44)$ & 1757.51 & 720.98 & 1754.12 & 1649.15 \\
Prob $>\chi^{2}$ & 0.0000 & 0.0000 & 0.0000 & 0.0000 \\
Hausman-Wu Test & $\mathrm{X}^{2}(1)=25.06$ & $\mathrm{X}^{2}(1)=30.66$ & $\mathrm{X}^{2}(1)=21.18$ & $\mathrm{X}^{2}(1)=5.39$ \\
$\mathrm{H}_{0}:$ Conflicts are exogenous. & $\mathrm{p}$-value $=$ & $\mathrm{p}$-value $=$ & $\mathrm{p}$-value $=$ & $\mathrm{p}$-value $=0.0202$ \\
& 0.0000 & 0.0000 & 0.0000 & \\
\hline
\end{tabular}

Estimated by Three-Stage Least Squares using predicted conflict as the single excluded instrument (Wooldridge 2002: 542). t-stats in parentheses. Statistical signif.: $1 \%^{* * *} .5 \%^{* *}, 10 \%{ }^{*}$. The coefficients for all four equations are constrained to add up to zero for every variable. 


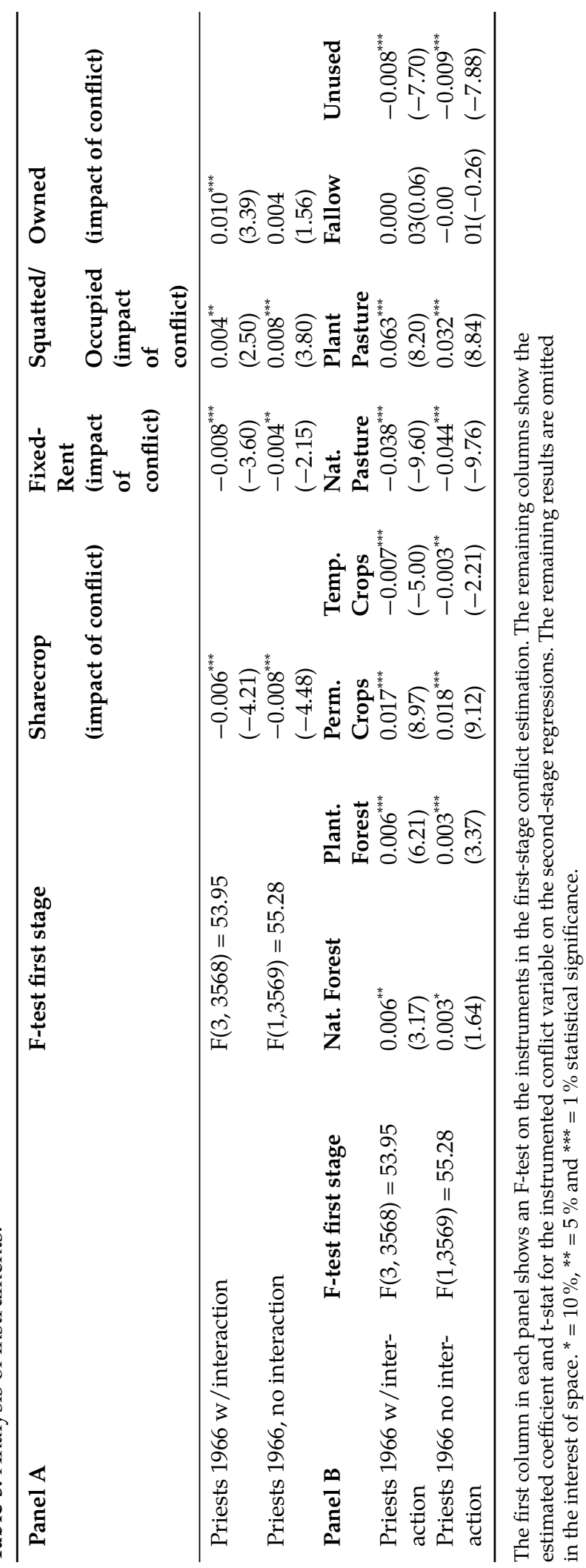


Apart from the frontier variable, none of the other geographic variables are statistically significant, though the effect of temperature and other climatic factors are also partially captured by the state dummies. Some variables that control for the level of agricultural activity in the county are found to be negative and statistically significant. These variables are the number of tractors per hectare and the proportion of rural to urban population. These results indicate that conflicts are less likely, ceteris paribus, where there is more rural economic activity. On the other hand, greater population growth from 1985 to 1995 - which includes migration - has a positive and significant effect on conflicts as does population density. Similarly, those municipios that experienced greater rates of GDP growth from 1985 to 1995 registered more violence. ${ }^{21}$ The data are very clear in showing that conflicts are more likely in regions where there are rents to be captured, a notion that is in line with several models of the evolution of property rights, such as Alston, Harris, and Mueller (2009) and Demsetz (1967). ${ }^{22}$

Finally, there are the crop mix variables, all in percent of total area for 1995. The results show that coffee and beans are less likely, ceteris paribus, to lead to conflict. Soybeans and sugarcane, on the other hand, are found to be positively associated with conflict. In addition, state dummies are statistically significant for several states, indicating that there are many idiosyncratic factors not captured in our other variables.

\subsection{Second stage: determinants of contract choice}

The objective of this second-stage regression is to test for the determinants of contract choice. The dependent variables are the percent of total farmland that is cultivated under fixed rent, sharecropping, by the owner, or cultivated without formal title. We estimate a system of four equations through seemingly unrelated regression. The advantage of this method is that we can restrict the coefficients of every variable in the four equations to add up to zero. This is desirable because the dependent variables are measured in percent of total farmland so that if a change in an independent variable causes one of the dependent variables to rise, this must be compensated with a decline in one or more of the other three dependent variables. Furthermore, because the conflict variable that enters each equation is endogenously estimated in the first stage, the method will actually be three-stage least squares, which besides applying instrumental variable estimation to each equation also controls for 'contemporaneous' correlation in the errors. A Hausman-Wu test in each of the four equations (see last line in Table 4) shows that instrumental variables are necessary. The exogeneity of conflicts is strongly rejected ( $1 \%)$ for the sharecropping, fixed rent and owner-cultivated equations, and at $5 \%$ for squatted/occupied land. We present the non-instrumented and thus not consistent results in Table A in Appendix B.

The purpose of the estimation is to ascertain the relative impacts of endowments and political/institutional factors on the form of agrarian organization. The endowments of a given county are captured by the crop mix that is found to prevail in 1995, the idea being that given relative prices, the choice of crops is overwhelmingly determined by agro-climatic and geographic factors, for example, you can't grow coffee too far south because of frost. We also use latitude and longitude coordinates as well as variables that measure distance to the state capital, transportation costs, the growth from 1985 to 1995 of the municipio's GDP, tractors, cattle, population growth, urbanization and population density as additional endowment controls to the crop mix variables.

We use the conflict variable that we estimated in the previous section to capture the political/institutional determinants of contract choice. The conflict variable includes any incidence of land-related violence that was registered from 1985 to 1995 by the CPT. The assumption is that the existence of such events in a municipio reflects a perception by economic agents of property rights insecurity that, given the biases in Brazilian land legislation and enforcement discussed in Section 2, may affect their choice of contract. Our interest is to determine both the direction and magnitude of conflict on contract choice. The conceptual framework in Section 2 demonstrated that property rights insecurity can impact the use of tenancy either negatively and positively, depending on how net present values of alternative land uses are affected in any given case. We present our estimation results in Table $4 .^{23}$

The results show that the crop mix in a given county affects the form of agrarian organization. Most of the estimated coefficients for the eight crops are statistically significant in each of the four equations. Both fixed-rent and sharecropping contracts are more probable where operators plant cotton, soybeans, rice and sugar cane; fixed rent is less probable where operators plant coffee and corn; and the planting of beans and manioc having no statistically significant effect. These results are compatible with generally held perceptions of the nature of these crops. For example, Almeida and Buainain (2001: 4-5) state that in Brazil, fixed-rent contracts are particularly intense in rice-growing areas. The magnitudes of the impacts of the crop variable will be discussed below in comparison to the impact of conflicts. First, we interpret the impact of the other variables. Latitude and/or longitude are statistically significant in all of the four equations except sharecropping, thereby increasing the confidence that we are controlling for geographic and climatic factors so that any effect captured by the conflict variable will be ceteris paribus. We found that counties that are more distant from the state capital used more sharecropping and were squatted less. Transport costs to São Paulo increased the area in squatting and reduced 
the owned area. The presence of train stations increased the area in fixed-rent contracts and reduced the owned area.

The positive effect of GDP growth from 1985 to 1995 on squatted areas and the negative effect on ownerrun areas is an indication that less-developed areas tended to grow more during this period. An increase in the number of tractors per hectare had the effect of causing municipios to be more sharecropper and squatter intensive to the detriment of owner-operated areas. Increases in cattle reduced squatted and increased owned area, while population density increased fixed rent and reduced owned areas. An increase in the proportion of rural to urban population increased the area of land operated by squatters and reduced that operated under fixed rent.

Conflicts per farm is the main variable of interest. The results show that increases in conflicts lead to lower use of fixed rent and sharecropping, with a corresponding increase in owner-run and squatted farms. All coefficients are statistically significant. This result provides strong evidence that property rights insecurity is detrimental to the adoption of tenancy arrangements and may have important efficiency effects as recognized by the large literature on the economics of agricultural organization. The evidence in our test corroborates for Brazil the hypotheses in Besley et al. (2011), Conning and Robinson (2007), and De Janvry and Sadoulet (1989) concerning the perverse effects of politics and conflict.

Not only are the impacts of conflicts and of the endowment variables significant, but they are also quite large. If all variables are set to their mean values and conflicts at zero, the predicted proportion of agricultural land in fixed rent and in sharecropping would be $7.3 \%$ and $3.2 \%$. If the number of conflicts is increased to 4.4 , which is the average number of conflicts per 1,000 farms in those municipios that had any conflicts, then those proportions drop to $3.8 \%$ and $0.4 \%$. That may not look like much of a drop, but if applied to total area in farms in the country, the reduction in area in fixed rent would be greater than the area of North Korea $(117,000 \mathrm{sq}$. $\mathrm{km}$.) and the reduction in sharecropping area would be greater than Portugal $(93,000 \mathrm{sq} . \mathrm{km})$.

Of the crop variables, the ones that had the greatest impact were cane, soybeans and rice. A one-standard deviation increase in the area dedicated to cane would increase, ceteris paribus, the proportion of area in fixed rent from $6.9 \%$ to $9.9 \%$ and in sharecropping from $3.2 \%$ to $4.2 \%$. This is equivalent to the area of South Korea (99,000 sq. km) and Azerbaijan (32,000 sq. km), respectively. The impact of soybeans on fixed-rent area would be an increase of $2.2 \%$, which also implies an increase the size of a small country if extended to the entire agricultural area of Brazil. Although the estimated coefficients in Table 4 are small, the impacts when extended to the entire country are very consequential.

Ideally, we would like to take into account in the estimation procedure the fact that spatial autocorrelation may be present, as several of the variables in a given municipio may be affected by the levels of the same variable in neighboring municipios. Our framework contained several indirect effects where landowners had their decisions affected by what happens to other farms. Presumably, conflicts in neighboring municipios could also affect their profit expectations. In the absence of an econometric procedure that allows us to control for spatial autocorrelation in the context of Three-Stage Least Squares estimation with a first-stage Tobit, in Appendix C we provide a sensitivity analysis using alternative estimating procedures and show that spatial autocorrelation, though present, does not affect the results significantly.

\subsection{Testing the appropriateness of the instruments}

In Section 3.2, we provided the historical and political rationale for why priests can be considered randomized for the purposes of estimating land use and contracts. In this section, we provide a statistical analysis of the instrument's appropriateness. For the results in Table 4 to be valid, the priest variable must have certain properties. The first is that it should have a clear effect on conflict. The second is that there must be no direct link between contract choice/land use and priests, except through the channel of conflicts. One way to test for the first property, that is, whether the instruments are weak, is through an F-statistic on the joint significance of the instruments in the first-stage regression (Stock, Wright, and Yogo 2002). If the F-statistic is greater than a given threshold value, then the instruments can be considered as not being weak. The threshold value at $5 \%$ for the case of 5 instruments is 9.20 (Stock, Wright, and Yogo 2002: Table 1 pg. 522). Table 5 shows the results for the contract choice equations, comparing the results shown in Table 4 with an alternative specification where the interaction term of priests and frontier is dropped. In both specifications, the null hypothesis of weak instruments is clearly rejected.

In order to test the second property of the instrument, that is, the exclusion restriction, a Sargan-Hansen statistic to test for overidentifying restrictions would be recommended. However, this is not possible in our case because the second stage is estimated using the fitted value from the first stage as a single instrument rather than plugging in the separate fitted values. This procedure is necessary because the first stage is nonlinear (Wooldridge 2002: 542; Angrist and Pischke 2009: 191). Applying 2SLS reasoning directly with a non-linear 
first stage is not guaranteed to produce first-stage residuals that are uncorrelated with fitted values and covariates. In any case, we show in Table 5 that our main results are robust to a different specification of the instruments. The results concerning the impact of property rights on contract choice still hold if priests are used as an instrument without the frontier interaction. There is some slight non-systematic variation in the magnitude of the coefficients, but the signs and statistical significance remain unchanged. ${ }^{24}$

\section{Concluding remarks}

In Brazil, land reform policy, by affecting the security of property rights via increasing land conflicts, has had a perverse impact on land rentals resulting in an inefficiency or inability to realize the gains from agricultural contracting. In a large commodity-based country like Brazil, the losses are undoubtedly high. Even if there are other reasons not related to land conflict for why some farmers may want to hold large and unproductive properties, such as to hedge against inflation (very relevant for the time period of our data) or for political power, it would still be advantageous to the prospective tenant and sharecroppers, as well as to society, for the landowner to rent the land and profit twice (Rezende 2006; Sayad 1982).

The very low levels of tenancy and productive land use in Brazil and much of Latin America are thus a puzzle. The difficulty of solving this paradox lays not so much in being able to point to causes of this behavior. In this article, we have provided very robust evidence that insecure property rights are an important deterrent to tenancy arrangements and more productive land use. The greater puzzle, as noted by Conning and Robinson (2007: 421), is why economic agents are not able to contract around these inefficiencies.

The extent of the losses from forgoing rental contracts in Brazil has in the recent past led to several attempts at getting around the impediments of tenancy by creating special regional programs where all the necessary conditions would be provided by policymakers and other organizations for rental transactions to take place. Buainain et al. (2008) survey some of these attempts and conclude that "however well considered the initiatives are, they have not achieved their goals ... county administrations do not manage to use either the incentives or the coercive instruments required to induce landowners and landless farmers to negotiate under equal conditions leading to mutually profitable contracts." It is the understanding of this greater inability to credibly commit to not expropriating rented farms and thereby the inability to realize the gains from contracting that is the real puzzle to be explained. Put another way: given that both landowners and tenants would benefit from more secure property rights, what are the impediments to a more sensible land reform policy? We conjecture that the answer rests on the politics of land reform, a debate that entails the entire electorate and not simply the parties to the contract. Given that Brazil has the highest land inequality in Latin America, with a highly urbanized and enfranchised citizenry, voters favor a land reform policy based on redistribution, which has the unintended consequence of increasing land conflicts and reducing the career mobility prospects of many landless rural peasants.

\section{Acknowledgements}

The authors acknowledge the support of the National Science Foundation (Grant 0528146). Mario Miranda and Adam Canton provided able research assistance organizing the data set. Thanks to Alexandre Iwata and IPEA for making the IPEAGeo 1.0.0 program available to us. We received extremely helpful comments from Ernesto dal Bo and Sebastian Galiani as discussants at the LACEA Political Economy Network Conference. We received further useful comments from Peter Houtzager, Madeleine Cousineau, Wolfgang Keller, Joseph Love, A. Mushfiq Mobarak, Charles Mueller, Décio Zylbersztajn, and participants at the following conferences and seminars: Conference on the Theory of Share Tenancy After 50 Years, 2017; NBER Summer Institute - Environment and Energy, 2010; LACEA Political Economy Network Conference, 2010 Cartagena; IV Research Workshop on Organizations and Institutions, São Paulo, 2009; International Society for New Institutional Economics Annual Meeting, 2009 Berkeley; IPEA-Brasília; IPEA-Rio de Janeiro; PUC-Rio de Janeiro; Universidade de Brasilia; Universidade Católica de Brasília; University of California, San Diego; University of Colorado; and University of Illinois.

\section{Notes}


1 The use of land rentals is relatively low across all of Latin America. De Janvry, Macours, and Sadoulet (2002) present tables showing the importance of land rentals across the world and for certain countries in Latin America. For the world, tenancy stood at $23 \%$ in 2000 (Federico 2006). In Brazil, for 1996, tenancy was $2.5 \%$ (of total hectares) and $11 \%$ (of the number of farms) (IBGE 2007).

2 The Landless Peasant Movement (MST) estimates that there are 4 million landless peasants in Brazil. However, this estimate includes all who are 'demanding land' and is broader than those with actual aptitude for agriculture and the intention to stay on the land.

3 By transaction costs, we mean the information, monitoring and enforcement costs associated with contracting. They include issues of moral hazard and adverse selection. We also follow in the footsteps of the agricultural economists analyzing tenancy in the early part of the twentieth century. For a review of some of the earlier work of agricultural economists, see Alston and Higgs (1982). For a seminal treatment, see Cheung (1969).

4 De Janvry, Macours, and Sadoulet (2002) provide a very helpful table of the 'contextual conditions' under

which each land tenure status is observed.

5 De Janvry, Macours, and Sadoulet (2002) found that in the Dominican Republic, landlords were more likely to rent to those in their same social network.

6 This was the case in the Pampas in Argentina under Peron (Gallo 2003), and in the Dominican Republic following legislation passed in 1972 (De Janvry, Macours, and Sadoulet 2002).

7 Brazil is probably not atypical in the long delays associated with assigning formal titles. In Mexico, until recently, the government forbade the renting of ejidos.

8 The actual decision would be between all the possible combinations of land contracts over time, such as waiting $x$ amount of time before renting the land, then renting it for at least the legislated minimum amount of time, then taking the land back for $y$ amount of time before renting it again or not. To simplify, we consider only the choice between renting now forever, and not renting at all. The basic point about the impact of property rights can be made without loss of generality in this simplified context.

9 In the Brazilian Agricultural Census, fixed rent are those properties that belong to a third party but are worked by a producer who pays a previously set fixed quantity in cash or its equivalent in products. Sharecroppers work properties that belong to a third party in exchange for a previously set proportion of the production. Occupants are those on land that belongs to some third party (may be public land) with no payment in exchange, which might be the case of squatting or of consensual cession of the use of the land. Owned land belongs to the producer on the land.

10 Potentially long-term leases could deal with the perennial nature of coffee, but perennial leases may be more problematic with respect to the legislation's emphasis on beneficial use, issues that we discuss shortly.

11 Other factors such as soil type, temperatures, rain, and sunshine are partially captured by state dummies.

12 For a very good discussion of the hostility towards tenancy arrangements in Brazilian legislation, see Rezende (2006), section 8. See also Romeiro and Reydon (1994).

13 To the present day, Brazil possesses very progressive labor laws conceding a wide set of benefits and privileges to rural and urban workers. Labor justice in Brazil almost always decides in favor of the employee, which at least reduces uncertainty. However, these benefits make for more rigid labor markets and may increase unemployment.

14 During much of the 1970s and 1980s, the lack of a more highly developed financial system meant that land ownership was a widely used instrument to hedge against inflation. This resulted in large areas of unproductive latifunidia despite the possibility for the owners to gain twice by renting the land out to productive use while still fulfilling its financial objective. Rezende (2006) argues that the lack of rentals results from the hostility of the agrarian legislation towards tenancy arrangements.

15 Pande and Udry (2006) provide a very detailed review of the literature on the effect of property rights on economic outcomes in agriculture in developing countries. In Table 5, they summarize numerous studies for many different countries. The results in the literature vary considerably leading the authors to conclude that "... land titling and registration typically increase agricultural productivity and farm investment. However, the extent of increase depends upon the details of the titling program and the pre-existing land tenure system." 16 Conflict data is only available for years since 1985.

17 During this period, there was actually a drop in the number of priests as fewer candidates were willing to undertake this career and lifestyle. This trend only changed in the late 1970s, as a rising supply of candidates from lower classes and rural backgrounds appeared to substitute for the dwindling number of middle-class candidates who had traditionally filled the ranks of the priesthood (Alberto 2003: 6). This fact may also be a cause and consequence of the Church's involvement in agrarian issues at that point in time.

18 We thank Mario Miranda and Adam Canton for research assistance preparing the data.

19 The index is merely additive instead of being created by principal components because most observations had no conflicts, and these methods do not work well when the series have many zeros.

20 The coefficient of the interaction term in Table 3 is the value that holds when the frontier index is zero, a value that makes no sense as the index starts at 1 . Similarly the reported standard deviation for the estimate of this coefficient ignores some covariance terms that should be taken into account. The correct formulas have been used in the interpretations in the text.

21 We used GDP growth rather than levels to reduce the possibility of endogeneity of GDP. Removing GDP from the equation has practically no effect on the other results.

22 Daniel et al. (2010) reach the opposite conclusion when estimating the impact of negative shocks to income on the number of land invasions, instrumented by the amount of rainfall, especially in municipios with higher income concentration. They find that agricultural income and land invasions are negatively correlated. The two studies are different in that their central interest is the impact of income on conflict, and we are estimating conflict in a first-stage regression where income is used merely as a control. We used agricultural GDP growth (1985-1996) rather than levels so as to attenuate the possibility of endogeneity of income. When income is excluded, all other results are practically unchanged.

23 Table 4 shows the results using data on priests for 1966. Using data on priests from 1970, 1980, 1985 or 1995 gives the same basic results, which once again shows that the distribution of priests has not changed dramatically across municipios over time. Results provided by the authors by request.

24 The results are also robust to using data on priests from other years after 1966.

\section{References}

Adriance, M.C. 1991. "Agents of Change: The Roles of Priests, Sisters, and Lay Workers in the Grassroots Catholic Church in Brazil," Journal for the Scientific Study of Religion 30(3): 292-305.

Adriance, M.C. 1992 . "The Paradox of Institutionalization: The Roman Catholic Church in Chile and Brazil." Sociological Analysis 53: S51- S62. 
Adriance, M.C. 1994. “Base Communities and Rural Mobilization in Northern Brazil,” Sociology of Religion 55(2): 163-178.

Adriance, M.C. 1995. "The Brazilian Catholic Church and the Struggle for Land in the Amazon," Journal for the Scientific Study of Religion 34(3): 377-382.

Alberto, A. 2003. A História Da OSIB E Os Desafios Da Formação. Belo Horizonte: $13^{\mathrm{a}}$ Assembléia da OSIB - Organização dos Seminários e Institutos do Brasil.

Almeida, P. 2002. Arrendamento e Acesso à Terra no Brasil. Master Dissertation at the University of Campinas, UNICAMP.

Almeida, P..., and A.M. Buainain. 2001. "Arrendamento De Terras: Uma Contribuição Ao Neoinstitucionalismo Econômico," in III International Conference on AgriChain/Networks Economics and Managemente, 10-30 Ribeirão Preto/SP - USP, - 24 a 26 de outubro de.

Alston, L.J., and J.P. Ferrie. 2005. “Time on the Ladder: Career Mobility in Agriculture 1890-1938," The Journal of Economic History 65(04): 10581081. Cambridge University Press.

Alston, L.J., E. Harris, and B. Mueller. 2009. “De Facto and De Jure Property Rights: Land Settlement and Land Conflict on the Australian, Brazilian and U.S. Frontiers" NBER Working Paper No. 15264, September.

Alston, L.J., and R. Higgs. 1982. "Contractual Mix in Southern Agriculture since the Civil War: Facts, Hypotheses and Tests," Journal of Economic History XLII(June): 327-353.

Alston, L.J., and K. Kauffman. 1997. “Agricultural Chutes and Ladders: New Estimates of Sharecroppers and 'True Tenants' in the South, 1900-1960." Journal of Economic History 57 (June): 464-475.

Alston, L.J., and K. Kauffman. 1998. "Up, down and off the Agricultural Ladder: New Evidence and Implications of Agricultural Mobility for Blacks in the Postbellum South," Agricultural History 72: 263-279.

Alston, L.J., G.D. Libecap, and B. Mueller. 1999a. "A Model of Rural Conflict: Violence and Land Reform Policy in Brazil," Environment and Development Economics 4: 135-160. Cambridge:UK.

Alston, L.]., G.D. Libecap, and B. Mueller. 1999b. Titles, Conflict and Land Use: The Development of Property Rights and Land Reform on the Brazilian Amazon Frontier. Ann Arbor: The University of Michigan Press.

Alston, L.J., C.D. Libecap, and B. Mueller. 2000. "Property Rights to Land and Land Reform: Legal Inconsistencies and the Sources of Violent Conflict in the Brazilian Amazon," Journal of Environmental Economics and Management 39: 162-188.

Alston, L.J., G.D. Libecap, and B. Mueller. 2010. “Interest Groups, Information Manipulation in the Media, and Public Policy: The Case of the Landless Peasants Movement in Brazil" NBER Working Paper No. 15865.

Alston, L.J., and J.P. Ferrie. 1999. Paternalism and the American Welfare State: Economics, Politics, and Institutions in the U.S. South. 1865-1965. New York: Cambridge University Press.

Angrist, J.D., and ].-S. Pischke. 2009. Mostly Harmless Econometrics: An Empiricist's Companion. Princeton, N]: Princeton University Press

Bank, W. 1994. Brazil: The Management of Agriculture, Rural Development and Natural Resources, Vol. 2 Background Papers. Latin America and the Caribbean Region: Natural Resource Management and Rural Poverty Division, Country Department. July 31.

Besley, T. 1995. “Property Rights and Investment Incentives: Theory and Evidence from Chana," Journal of Political Economy 103(5): 903-937.

Besley, T., J. Leight, R. Pande, and V. Rao. 2011. “The Regulation of Markets: Evidence from Tenancy Reform in India," London School of Economics, Economic Organization and Public Policy Series Discussion Paper EOPP/2011/31.

Binswanger, H.P., K. Deininger, and G. Feder. 1995. "Power, Distortions, Revolt and Reform in Agricultural Land Relations," in J. Behrman and T.N. Srinivasan ed. Handbook of Development Economics, Volume III, 2659-2772. Amsterdam: Elsevier Science.

Brandão, A.S., C.S. Bastos Filho, and A.P. Brandão. 2001. “Land Markets and Rural Poverty Alleviation," Chapter 4 in World Bank, Rural Poverty Alleviation in Brazil: Towards an Integrated Strategy-Vol. 1: Policy Summary, World Bank, Report No. 21790-BR

Brito, L.L. 2010. “Medellín E Puebla: Epicentros Do Confronto Entre Progressistas E Conservadores Na América Latina," Revista Espaço Acadêmico 111 (Agosto): 81-89.

Bruneau, T. 1985. "Church and Politics in Brazil: The Cenesis of Change," Journal of Latin American Studies 17: 271-293.

Buainain, A.M., P.J. Almeida, F. De Lima, and J.M. De Silveira. 2008. “Land Rental Markets and Land Access in Brazil," Basis Brief: Assets and Market Access, CRSP, July, http://www.basis.wisc.edu.

Carter, M.R., and P. Olinto. 2003. “Cetting Institutions ‘Right' for Whom? Credit Constraints and the Impact of Property Rights on the Quantity and Composition of Investment," American Journal of Agricultural Economics 85: 173-186.

Carvalho, M.S. 1991. “A Pequena Produção De Café No Paraná," PhD diss. University of São Paulo, Dept. of Ceography.

CERIS - Centro de Estudos Religiosos e Investigações Sociais. Anuário Católico Do Brasil. Vol. 10, 1-973. Rio de Janeiro: CERIS

Cheung, S.N.S. 1969. The Theory of Share Tenancy. Chicago: University of Chicago Press.

CNBB - Confederação Nacional dos Bispos Brasilieros. 1980. Igreja E Problemas Da Terra. São Paulo: Ed. Paulinas.

Conley, T.C. 1999. “GMM Estimation with Cross Sectional Dependence," Journal of Econometrics 92: 1-45.

Conning, J.H., and J.A. Robinson. 2007. "Property Rights and the Political Organization of Agriculture," Journal of Development Economics 82 : 416-447.

Daniel, H.F., S. Naidu, S. Nichter, and N. Richardson. 2010. “2010." The Review of Economics and Statistics 92(3): 505-523.

De Janvry, A., K. Macours, and E. Sadoulet. 2002. Access to Land in the Rural Development Agenda. Washington D.C: Sustainable Development Department, Inter-American Development Bank.

De Janvry, A., and E. Sadoulet. 1989. "A Study in Resistance to Institutional Change: The Lost Came of Latin American Land Reform," World Development 17(9): 1397-1407.

Deininger, K., and D.A. Ali. 2008. “Do Overlapping Land Rights Reduce Agricultural Investment? Evidence from Uganda," American Journal of Agricultural Economics 90(4): 869-882. http://ssrn.com/abstract=1263062.

Deininger, K., and J.S. Chamorro. 2004. “Investment and Equity Effects of Land Regularisation: The Case of Nicaragua." Agricultural Economics 30 (2): 101-116.

Demsetz, H. 1967. “Towards a Theory of Property Rights," The American Economic Review 57: 347-359. 2 May, 1967.

Economist, The 2011. Employer, Beware. 43 March12th-18th2011.

Federico, C. 2006. “The 'Real' Puzzle of Sharecropping: Why Is It Disappearing?," Continuity and Change 21(2): 261-285.

Gallo, A. 2003. “Rural Rent Legislation in Argentina: Congress and Renters, 1912-1943," Working Paper. 
Garcia-Jimeno, C., and J.A. Robinson. 2009. "The Myth of the Frontier," NBER Working Paper Series w14774(March): 2009. Available at SSRN: http://ssrn.com/abstract=1352954

Chatak, M., and S. Roy. 2007. "Land Reform and Agricultural Productivity in India: A Review of the Evidence," Oxford Review of Economic Policy 23(2): 251-269. Available at SSRN: http://ssrn.com/abstract=1151129

Hewitt, W.E. 1990. "Religion and Consolidation of Democracy in Brazil: The Role of the Comunidades Eclesiais De Base (Cebs)," Sociological Analysis 50(2): 139-152.

Houtzager, P.P. 2001. “Collective Action and Political Authority: Rural Workers, Church, and State in Brazil," Theory and Society 30 (1, Feb): 1-45. IBCE. 1984. Áreas Mínimas De Comparação a Nível Municipal: 1980-1970-1960. Rio de Janeiro: IBCE.

IBCE. 2007. Séries Estatísticas \& Séries Históricas, Rio De Janeiro, IBCE, Censo Agropecuário 1920 to 1995/96: http://www.ibge.gov.br/series_estatisticas/subtema.php?idsubtema=100.

IPARDES. 1978. O Trabalhador Volante No Estado Do Paraná. Vol. I. Curitiba. IPARDES.

Jaramillo, C.F. (2001). El Mercado Rural de Tierras em America Latina: Hacia uma Nova Estatrategia. Washington, DC: Inter-American Development Bank, Technical Report No. EVN-124.

Krischke, P.]. 1991. “Church Base Communities and Democratic Change in Brazilian Society,” Comparative Political Studies 24(2): 186-210.

Mainwaring, S. 1986. The Catholic Church and Politics in Brazil, 1916-1985. Stanford: Stanford University Press.

Mainwaring, S., and A. Wilde. 1989. The Progressive Church in Latin America.. Notre Dame, IN: University of Notre Dame Press/Kellogg Institute.

Marshall, A. 1890. Guillebaud, C.W. (Ed.) Principles of Economics. London: Macmillan Company (1961)

Martins, J.S. 1980. “O Documento Da Terra Prometida," Reforma Agrária: Boletim Da Associação Brasileira De Reforma Agrária 2: 39-43. Unicamp, Ano X, Mar./Abr.

Maybury-Lewis, B. 1994. The Politics of the Possible: The Brazilian Rural Worker's Trade Union Movement, 1964-1985. Philadelphia: Temple University Press.

McDonald, J.F., and R.A. Moffit. 1980. "The Uses of Tobit Analysis," The Review of Economics and Statistics 62(2, May): 318-321.

Menezes Neto, A.J. 2007. “A Igreja Católica E Os Movimentos Sociais Do Campo: A Teologia Da Libertação E O Movimento Dos Trabalhadores Sem Terra," Cadernos Do CRH (UFBA) 20: 331-342.

Menezes Neto, A.J. 2009. A Igreja Católica E A Luta Pela Terra No Brasil. 1-16. IV Simpósio Internacional de Ceografia Agrária Niteroi: SINCA.

Moura, M.J.S.B., and L.S.B. Rodrigo. 2009. "How Land Title Affects Income," ANPEC - Brazilian Association of Graduate Programs in Economics, Proceedings of the 37th Brazilian Economics Meeting. 203.

Nichols, W.H. 1971. “A Fronteira Agrícola Na História Recente Do Brasil: O Estado Do Paraná, 1920-65," Revista Paranaense De Desenvolvimento 26: 19-53. Curitiba, set-out.

Pande, R., and C. Udry. 2006. "Institutions and Development: A View from Below," with Chris Udry in Proceedings of the 9th World Congress of the Econometric Society, eds. R. Blundell, W. Newey and T. Persson, Cambridge University Press.

Pinckney, T.C., and P.K. Kimuyu. 1994. “Land Tenure Reform in East Africa: Cood, Bad or Unimportant?," Journal of African Economies 3(1): 1-28.

Place, F., and K. Otsuka. 2002. "Land Tenure Systems and Their Impacts on Agricultural Investmetns and Productivity in Uganda," Journal of Development Studies 38(6): 105-124.

Reis, E., M. Pimentel, and A.I. Alvarenga. 2009. Áreas Mínimas Comparáveis Para Os Períodos Intercensitários De 1872 a 2000. Rio de Janeiro: IPEADIMAC.

Rezende, G.C. 2006. “Políticas Trabalhista, Fundiária E De Crédito Agrícola No Brasil: Uma Avaliação Crítica,” Revista De Economia E Sociologia Rural 44(1): 47-78

Rezende, G.C., and A.C. Kreter. 2007. "“'Agricultural Labor Legislation and Poverty in Brazil," A Transaction Costs Approach” Revista De Economia Agrícola 54: 121-137.

Ribeiro, M.C.M., and M.I. Stolf. 1975. “A Moradia Do Trabalhador Na Fazenda De Café Paulista.”. In Carone, E. (Ed.), O Café: Anais Do II Congresso De História De São Paulo. 135-156. São Paulo: Instituto Historico e Ceografico Brasileiro

Romeiro, A., and B.P. Reydon. coords. 1994. O Mercado De Terras. Brasília: IPEA. 1994, Estudos de Política Agrícola (Documentos de Trabalho, 13).

Saint, W.S. 1980. “Mão-de-Obra Volante Na Agricultura Brasileira: Uma Revisão Da Bibliografia," Pesquisa E Planejamento Econômico IPEA 10(2): 503-526. Agosto.

Sayad, J. 1982. “Especulação Com Terras Rurais: Efeitos Sobre a Produção Agrícola E O Novo ITR," Pesquisa E Planejamento Econômico 12(1): 87-108. abr.

Serbin, K.P. 2000. “The Catholic Church, Religious Pluralism, and Democracy in Brazil.". In Kingstone, P.R., and T.J. Powers (Eds.) Democratic Brazil: Actors, Institutions, and Processes. Pittsburgh, PA: University of Pittsburgh Press.

Skidmore, T. 2003. Uma História Do Brasil. 4th edition. São Paulo: Paz e Terra.

Stock, J.H., J.H. Wright, and M. Yogo. 2002. "A Survey of Weak Instruments and Weak Identification in Ceneralized Method of Moments," Journal of Business \& Economic Statistics, October 20(4): 518-529.

(US Department of Agriculture) (2007).Census of Agriculture: U.S. National Level DataVol. 1, Chapter 1, Complete Report, Table 58, https://www.agcensus.usda.gov/Publications/2007/Full_Report/Volume_1,_Chapter_1_US/st99_1_058_058.pdf.

Vertova, P. 2006. "Property Rights on Unused Asset and Investment Incentives: Evidence from Brazil," Tilburg University, Center for Economic Research, Discussion Paper 48.

Wooldridge, J.M. 2002. Econometric Analysis of Cross Section and Panel Data. Cambridge, MA: MIT Press 


\section{Appendix}

\section{A Data}

Total number of observations $=3,659$. This the AMC7097 grouping created by IPEA/IBGE that makes data comparable from 1970 to 2000 by adding, or in some cases averaging, the data of municipios that subdivided from 1970 to 1997 . There are 27 states. The data for most of the variables are available for two set of years, 1985 and 1995/96. Agricultural data and Priest data can be added for 1980 and 1975, but Conflict data only goes back to 1985 . Not all variables are used in the estimation, but we list all variables available.

\section{Agricultural data (source $=$ IBCE Agricultural Census)}

1. Area in farms (1985 and 1996), hectares.

2. Number of establishments (1985 and 1996).

3. Total municipio area (fixed)

4. Farm area in natural forest (1985 and 1996), hectares.

5. Farm area in planted forest (1985 and 1996), hectares.

6. Farm area in permanent crops (1985 and 1996), hectares.

7. Farm area in temporary crops (1985 and 1996), hectares.

8. Farm area in natural pasture (1985 and 1996), hectares.

9. Farm area in planted pasture (1985 and 1996), hectares.

10. Farm area left fallow (1985 and 1996), hectares.

11. Farm area productive but not used (1985 and 1996), hectares.

12. Farm area unsuitable for productive use (1985 and 1996), hectares.

13. Total area in owner-run farms (1985 and 1996), hectares.

14. Total number of owner-run farms (1985 and 1996).

15. Total area in rented farms (1985 and 1996), hectares.

16. Total number of rented farms (1985 and 1996).

17. Total area in sharecropped farms (1985 and 1996), hectares.

18. Total number of sharecropped farms (1985 and 1996).

19. Total area in squatted farms (1985 and 1996), hectares.

20. Total number of squatted farms (1985 and 1996).

21. Number of heads of cattle (1985 and 1996).

22. Number of tractors (1985 and 1996).

23. Investments realized in the year R\$ (thou) of 2000(mil) (Deflated) (1985 and 1996).

24. Revenues received in the year R $\$$ (thou) of 2000(mil) (Deflated) (1985 and 1996).

25. Expenditures in the year R\$ (thou) of 2000(mil) (Deflated) (1985 and 1996).

26. Area irrigated (1985 and 1996), hectares.

27. Total number of tractors in the municipio (1985 and 1996).

28. People working in farms (1985 and 1996). 
29. Area in cotton (1985 and 1996), hectares.

30. Area in rice (1985 and 1996), hectares.

31. Area in coffee (1985 and 1996), hectares.

32. Area in sugar cane (1985 and 1996), hectares.

33. Area in beans (1985 and 1996), hectares.

34. Area in manioc (1985 and 1996), hectares.

35. Area in corn (1985 and 1996), hectares.

36. Area in soy beans (1985 and 1996), hectares.

\section{Conflict data}

37. Number of murders, yearly data (1985 to 1995). (Pastoral Land Commission)

38. Number of threats of murder, yearly data (1985 to 1995). (Pastoral Land Commission)

39. Number of murder attempts, yearly data (1985 to 1995). (Pastoral Land Commission)

40. Number of occupations/invasions, yearly data (1988 to 1995). (Pastoral Land Commission)

41. Area expropriated for land reform, yearly data (1979 to 1996). (INCRA/Ipeadata)

42. Capacity for settling families in settlement projects, yearly data (1979 to 1996), unit = families. (INCRA/Ipeadata)

43. Number of expropriations, yearly data (1979 to 1996). (Pastoral Land Commission) (INCRA/Ipeadata)

\section{Priest data (source Catholic Hierarchy-The hierarchy of the Catholic Church http://www.catholic-hierarchy.org/)}

44. Number of Catholics, data for 1966, 1975, 1985, 1995 (proximate years in some cases).

45. Total population (data from Catholic Hierarchy, not IBGE), for 1966, 1975, 1985, 1995 (proximate years in some cases).

46. Number of priests in Diocese, data for 1966, 1975, 1985, 1995 (proximate years in some cases).

47. Number of Catholics per priest, for 1966, 1975, 1985, 1995 (proximate years in some cases).

\section{Other data}

48. Area of entire municipio, square kilometers (oddly this varies from 1985 to 1996) (IBGE/Ipeadata).

49. Distance from the municipio head to the federal capital, kilometers, fixed for 1985 and 1996.

50. Distance to the state capital kilometers, fixed for 1985 and 1996.

51. Transport cost to São Paulo (index) - Nucleo de Estudos e Modelos Espaciais Sistêmicos, http:/ / www.nemesis.org.br/.

52. Number of train stations in the município - Nucleo de Estudos e Modelos Espaciais Sistêmicos, http://www.nemesis.org.br/.

53. Latitute, degrees, fixed for 1985 and 1996.

54. Longitude, degrees, fixed for 1985 and 1996.

55. Total population, 1980 and 1996. (IBGE/Ipeadata) 
56. Total rural population, 1980 and 1996. (IBGE/Ipeadata)

57. Total urban population, 1980 and 1996. (IBGE/Ipeadata)

58. Economically active population, 1985 and 1996. (IBGE/Ipeadata)

59. Economically active rural population, 1985 and 1996. (IBGE/Ipeadata)

60. Economically active urban population, 1985 and 1996. (IBGE/Ipeadata)

61. County GDP in R\$ of 2000 (thou) (deflated), 1985 and 1996. (IBGE/Ipeadata)

62. County agricultural GDP in R\$ of 2000 (thou) (deflated), 1985 and 1996. (IBGE/Ipeadata)

Table A: Non-instrumented results.

\begin{tabular}{|c|c|c|c|c|}
\hline & Fixed rent $(\%)$ & $\begin{array}{l}\text { Sharecropper } \\
(\%)\end{array}$ & Owner (\%) & $\begin{array}{l}\text { Squatted/Occupant } \\
(\%)\end{array}$ \\
\hline Conflict per 1000 farms & $\begin{array}{l}0.0002 \\
(1.41)\end{array}$ & $\begin{array}{l}-0.00004 \\
(-0.42)\end{array}$ & $\begin{array}{l}-0.0001 \\
(-0.31)\end{array}$ & $\begin{array}{l}-0.0001 \\
(-0.81)\end{array}$ \\
\hline Cotton, $\%$ of total farm & $0.463^{* * *}$ & $0.208^{* * *}$ & $-0.734^{* * *}$ & 0.062 \\
\hline area & $(5.93)$ & $(4.33)$ & $(-6.59)$ & $(0.91)$ \\
\hline Rice, $\%$ of total farm area & $\begin{array}{l}0.308^{* * *} \\
(8.72)\end{array}$ & $\begin{array}{l}0.252^{* * *} \\
(11.53)\end{array}$ & $\begin{array}{l}-0.553^{* * *} \\
(-10.96)\end{array}$ & $\begin{array}{l}-0.007 \\
(-0.23)\end{array}$ \\
\hline Coffee, $\%$ of total farm area & $\begin{array}{l}-0.127^{* * *} \\
(-4.70)\end{array}$ & $\begin{array}{l}0.056^{* * *} \\
(3.35)\end{array}$ & $\begin{array}{l}0.101^{* * *} \\
(2.63)\end{array}$ & $\begin{array}{l}-0.030 \\
(-1.29)\end{array}$ \\
\hline Cane, $\%$ of total farm area & $\begin{array}{l}0.175^{* * *} \\
(22.63)\end{array}$ & $\begin{array}{l}0.059^{* * *} \\
(12.33)\end{array}$ & $\begin{array}{l}-0.210^{* * *} \\
(-19.03)\end{array}$ & $\begin{array}{l}-0.024^{* * *} \\
(-3.56)\end{array}$ \\
\hline Beans, $\%$ of total farm area & $\begin{array}{l}0.0008 \\
(0.03)\end{array}$ & $\begin{array}{l}0.128^{* * *} \\
(8.09)\end{array}$ & $\begin{array}{l}-0.231^{* * *} \\
(-6.31)\end{array}$ & $\begin{array}{l}0.102^{* * *} \\
(4.56)\end{array}$ \\
\hline $\begin{array}{l}\text { Manioc, \% of total farm } \\
\text { area }\end{array}$ & $\begin{array}{l}0.047 \\
(1.20)\end{array}$ & $\begin{array}{l}0.086^{* * *} \\
(3.52)\end{array}$ & $\begin{array}{l}-0.676^{* * *} \\
(-12.02)\end{array}$ & $\begin{array}{l}0.543^{* * *} \\
(15.80)\end{array}$ \\
\hline Corn, $\%$ of total farm area & $\begin{array}{l}-0.027 \\
(-1.45)\end{array}$ & $\begin{array}{l}0.032^{* * *} \\
(2.74)\end{array}$ & $\begin{array}{l}-0.001 \\
(-0.04)\end{array}$ & $\begin{array}{l}-0.006 \\
(-0.34)\end{array}$ \\
\hline $\begin{array}{l}\text { Soy Beans, \% total farm } \\
\text { area }\end{array}$ & $\begin{array}{l}0.213^{* * *} \\
(16.66)\end{array}$ & $\begin{array}{l}0.028^{* * *} \\
(3.53)\end{array}$ & $\begin{array}{l}-0.212^{* * *} \\
(-11.63)\end{array}$ & $\begin{array}{l}-0.029^{* *} \\
(-2.58)\end{array}$ \\
\hline Frontier & $\begin{array}{l}-0.0004^{* * *} \\
(-2.67)\end{array}$ & $\begin{array}{l}0.0001 \\
(0.62)\end{array}$ & $\begin{array}{l}0.0009^{* * *} \\
(4.78)\end{array}$ & $\begin{array}{l}-0.0006^{* * *} \\
(-4.71)\end{array}$ \\
\hline GDP growth 1985-1995 & $\begin{array}{l}0.0002 \\
(0.15)\end{array}$ & $\begin{array}{l}-0.0005 \\
(-0.58)\end{array}$ & $\begin{array}{l}-0.006^{* * *} \\
(2.75)\end{array}$ & $\begin{array}{l}0.006^{* * *} \\
(4.75)\end{array}$ \\
\hline Latitude & $\begin{array}{l}-0.003^{* * *} \\
(-4.10)\end{array}$ & $\begin{array}{l}0.0009^{* *} \\
(2.23)\end{array}$ & $\begin{array}{l}0.004^{* * *} \\
(4.18)\end{array}$ & $\begin{array}{l}-0.002^{* * *} \\
(-3.72)\end{array}$ \\
\hline Longitude & $\begin{array}{l}0.001 \\
(1.43)\end{array}$ & $\begin{array}{l}0.0008^{*} \\
(1.89)\end{array}$ & $\begin{array}{l}-0.005^{* * *} \\
(-5.57)\end{array}$ & $\begin{array}{l}0.004^{* * *} \\
(6.13)\end{array}$ \\
\hline Distance to state capital & $\begin{array}{l}-0.00003^{* * *} \\
(-3.21)\end{array}$ & $\begin{array}{l}0.00001 \\
(1.18)\end{array}$ & $\begin{array}{l}0.00004^{* * *} \\
(3.53)\end{array}$ & $\begin{array}{l}-0.00002^{* * *} \\
(-2.93)\end{array}$ \\
\hline Transport cost to São Paulo & $\begin{array}{l}-0.000001 \\
(-0.54)\end{array}$ & $\begin{array}{l}-0.000003^{* *} \\
(-1,99)\end{array}$ & $\begin{array}{l}-0.00001^{*} \\
(1.90)\end{array}$ & $\begin{array}{l}0.00001^{* * *} \\
(5.14)\end{array}$ \\
\hline Number of train stations & $\begin{array}{l}0.002^{* * *} \\
(3.69)\end{array}$ & $\begin{array}{l}-0.0004 \\
(-1.49)\end{array}$ & $\begin{array}{l}-0.002^{* * *} \\
(2.72)\end{array}$ & $\begin{array}{l}0.0006 \\
(1.27)\end{array}$ \\
\hline Population density 1995 & $\begin{array}{l}0.00001 \\
(0.99)\end{array}$ & $\begin{array}{l}-0.0000003 \\
(-0.10)\end{array}$ & $\begin{array}{l}-0.00001 \\
(-0.96)\end{array}$ & $\begin{array}{l}0.000002 \\
(0.49)\end{array}$ \\
\hline $\begin{array}{l}\text { Rural/Urban Population } \\
1995\end{array}$ & $\begin{array}{l}-0.0008 \\
(-1.45)\end{array}$ & $\begin{array}{l}-0.0001 \\
(-0.22)\end{array}$ & $\begin{array}{l}-0.001 \\
(-1.57)\end{array}$ & $\begin{array}{l}0.002^{* * *} \\
(4.39)\end{array}$ \\
\hline $\begin{array}{l}\text { Population growth 1985- } \\
1995\end{array}$ & $\begin{array}{l}-0.001 \\
(-0.99)\end{array}$ & $\begin{array}{l}-0.0007 \\
(-0.69)\end{array}$ & $\begin{array}{l}0.003 \\
(1.15)\end{array}$ & $\begin{array}{l}-0.009 \\
(-0.64)\end{array}$ \\
\hline Tractor per hectare growth & -0.081 & $0.636^{* * * *}$ & $-0.976^{* * *}$ & $0.421^{* * *}$ \\
\hline 1985-1995 & $(-0.46)$ & $(5.88)$ & $(3.90)$ & $(2.75)$ \\
\hline Cattle per hectare1995 & $\begin{array}{l}-0.004^{* *} \\
(-2.13)\end{array}$ & $\begin{array}{l}-0.002 \\
(-1.43)\end{array}$ & $\begin{array}{l}0.009^{* * *} \\
(3.75)\end{array}$ & $\begin{array}{l}-0.004^{* * *} \\
(-2.68)\end{array}$ \\
\hline Constant & $\begin{array}{l}-0.054 \\
(-1.21)\end{array}$ & $\begin{array}{l}-0.028 \\
(-1.01)\end{array}$ & $\begin{array}{l}1.26^{* * *} \\
(19.86)\end{array}$ & $\begin{array}{l}-0.181^{* * *} \\
(-4.66)\end{array}$ \\
\hline Number of observations & Total: 3616 & Total: 3616 & Total: 3616 & Total: 3616 \\
\hline State dummies (27 states) & Yes & Yes & Yes & Yes \\
\hline $\mathrm{R}^{2}$ & 0.44 & 0.28 & 0.42 & 0.42 \\
\hline
\end{tabular}




\begin{tabular}{lllll}
$\chi^{2}(44)$ & 2835.14 & 1404.88 & 2033.70 & 2587.83 \\
Prob $>\chi^{2}$ & 0.0000 & 0.0000 & 0.0000 & 0.0000 \\
\hline
\end{tabular}

Estimated Seemingly Unrelated Regresion. t-stats in parentheses. Statistical signif.: $1 \%{ }^{* * *} .5 \%{ }^{* *}, 10 \%{ }^{*}$. The coefficients for all four equations are constrained to add up to zero for every variable.

\section{Sensitivity Analysis for Spatial Autocorrelation}

Ideally, we would like to take into account the effect of spatial autocorrelation in our regressions in Table 4 . Although we are able to run estimation procedures controlling for spatial autocorrelation using latitude and longitude to indicate each municipio's location, we have not found any program or routine that can do so in the context of three-stage least squares estimation with all coefficients of the same variable constrained to add up to zero across equations and when the first stage is a Tobit. Therefore, for the purpose of sensitivity analysis, we did three separate estimation procedures that can be compared to ascertain the relative impact on results of spatial autocorrelation versus the 3SLS. The first step is to use GMM estimation with the estimated level of conflict from the first-stage Tobit directly in each separate second-stage contract-choice equation. This procedure was then repeated including an additional procedure (Conely, 1999) that takes into account also the possibility of spatial autocorrelation of errors, that is, the impact of neighboring municipios' variables on a given município's dependent variable. The estimates from the two GMM procedures can be compared to see how much spatial autocorrelation affects the results. The second step is a comparison of the 3SLS results in Table 4 and the non-spatial GMM estimation in order to ascertain how much of the former results are due to taking into account contemporaneous correlation and to constraining the coefficients to add up to zero. The relative impacts of spatial autocorrelation and of the 3SLS can then be compared. The estimated coefficient of conflict in the contract-choice equations is shown in Table B.25

Table B: Sensitivity analysis for estimation procedure.

\begin{tabular}{llllll}
\hline & $\begin{array}{l}\text { Coefficient of Estimated Conflict (from 1st } \\
\text { stage) in Contract Equations }\end{array}$ & $\begin{array}{l}\text { Fixed Rent } \\
\mathbf{( \% )}\end{array}$ & $\begin{array}{l}\text { Sharecrop } \\
\mathbf{( \% )}\end{array}$ & Owner (\%) & $\begin{array}{l}\text { Squatted/Occupant } \\
(\mathbf{\%})\end{array}$ \\
\hline \multirow{2}{*}{1} & Three Stage Least Squares, Instrumental vari- & $-0.008^{* * *}$ & $-0.006^{* * *}$ & $0.010^{* * *}$ & $0.004^{* *}$ \\
& ables, no spatial correction (Table 3) & $(-3.60)$ & $(-4.21)$ & $(3.39)$ & $(2.50)$ \\
2 & GMM Instrumental variables, separate equa- & $-0.020^{*}$ & $-0.010^{* *}$ & $0.033^{* * *}$ & $-0.004^{*}$ \\
& tions, no spatial correction & $(-1.82)$ & $(-2.38)$ & $(2.68)$ & $(-1.65)$ \\
3 & GMM instrumental variable, spatial autocor- & -0.020 & $-0.011^{*}$ & $0.033^{* *}$ & -0.004 \\
& relation (Conley 1999) & $(-1.63)$ & $(-1.92)$ & $(2.16)$ & $(-1.46)$ \\
& Number of observations & 3616 & 3616 & 3616 & 3616 \\
\hline
\end{tabular}

Lines 2 and 3 estimated using IPEAGeo 1.0.0. t-stat in parentheses. Statistical significance: $1 \%{ }^{* * *}, 5 \%{ }^{* *}, 10 \%{ }^{*}$. Spatial GMM based on Conley (1999) using latitude and longitude as $\mathrm{x}$ and y coordinates with proportional distance set at $10 \%$ of maximum distance. Same controls used as in Table 4 except state dummies.

Line 1 in Table B shows the estimated coefficient for conflict using 3SLS, replicated from Table 4 . Line 2 shows the GMM estimates with no consideration of spatial autocorrelation. Finally, line 3 shows the GMM estimates including the correction for autocorrelation. Comparison of lines 2 and 3 shows the impact of spatial autocorrelation on the standard errors. By construction, the estimated coefficients are the same. Comparison of lines 1 and 2, none of which consider spatial autocorrelation, shows the impact of estimating the equations in a system by 3SLS with constrained coefficients rather than estimating separate equations through GMM, though the same instruments are used in both procedures.

The comparisons show that including the impact of spatial autocorrelation has very little impact on the tstats, which become slightly smaller but do not change the result of the tested hypotheses. In both cases, conflicts are found to reduce fixed rent and sharecropping, though no effect is found on squatted/occupied land. On the other hand, the impact of using 3SLS is large. The estimated coefficients vary and the $t$-stats become larger, adding substantial statistical significance to the result that the tenancy contracts are inhibited by conflict. The 3SLS results are preferable to the GMM results because they are more efficient econometrically. This is so for two reasons. The first is that the simultaneous estimation of the equations including the 'contemporaneous' correlation of errors makes the estimates more efficient. The second is due to the additional information that is added by the constraints that force all coefficients of each variable to add up to zero across equations. The 
upshot is that we can have confidence in the results presented in Table 4, with perhaps a small but inconsequent underestimation of the standard errors. 